\title{
UNA VISIÓN DE LOS DERECHOSY GARANTÍAS CONSTITUCIONALES DE LOS EXTRANJEROS EN ESPAÑA
}

\author{
POR \\ JOSÉ ÁNGEL.MARÍN GÁMEZ \\ Profesor Titular de Derecho Constitucional. \\ Universidad de Jaén
}




\section{SUMARIO}

1.- INTROdUCCIÓN. 2.- Algunos Conceptos y CATEgorías Útiles. 3.- Datos Y CIFRAS PARA EL ANÁLISIS. 3.1. Cifras, integración y conflictos. 3.2. Subempleo, economia sumergida $y$ trabajo clandestino. 4.- EXTRANJERÍA Y CIUDADANÍA EN LA Unión Europea. 5.- Derechos constitucionales de los eXtranjeros. 5.1. Al menos tres grandes grupos de derechos constitucionales vinculados a la extranjería. 5.2. Desglose. 6.- NORMATIVA SOBRE EXTRANJERIA Y SUS REFORMAS. 7.LA TERCERA REGULACIÓN SOBRE EXTRANJERÍA EN TRES AÑOS (LA CUARTA DESDE 1985): ANÁLISIS PRELIMINAR DE LA RECIENTE LEY ORGÁNICA 14/2003, DE 20 DE NOVIEMBRE, (BOE 21-XI-03). 8.- GARANTÍAS DE LOS DERECHOS. 9.- A MODO DE CONCLUSIÓN 


\section{UNA VISIÓN DE LOS DERECHOS Y GARANTÍAS CONSTITUCIONALES DE LOS EXTRANJEROS EN ESPAÑA}

POR

JOSÉ ÁNGEL MARÍN GÁMEZ

ProfesorTitular de Derecho Constitucional. Universidad de Jaén

\section{INTRODUCCIÓN}

La cuestión que vamos a abordar nos obliga a algunos planteamientos previos que pasan necesariamente por una rápida ojeada a ciertas macromagnitudes políticas, sociales y económicas de notable incidencia histórica. En el plano largo el asunto que tratamos está muy relacionado con el crecimiento de la población mundial, en particular, con las enormes diferencias entre la evolución demográfica de las naciones pobres o en vías de desarrollo $y$ de las naciones industrializadas. No es un descubrimiento que mientras que las primeras se enfrentan a los desequilibrios generados por el exceso de población, las segundas asisten impávidas al descenso progresivo del número de sus propios nacionales. La desproporción entre las tasas de crecimiento de la población de los países ricos y los pobres amenaza con presentar serios problemas en los próximos años. Las escasas posibilidades reales de los países en vías de desarrollo de incrementar su producción de bienes y servicios así como de dotarse de infraestructuras aceptables como para satisfacer las necesidades básicas de sus habitantes, provocan indefectiblemente huidas por la frontera empujados como están los que emigran por las dificultades de existencia en su lugar 
de origen. Este impulso migratorio hacia la bonanza transfronteriza en la búsqueda de mejores oportunidades de vida, genera efectos de diversa índole en los países de acogida, y que en el terreno que nos ocupa justo es constatar la patente insuficiencia de los mecanismos estrictamente jurídicos para dar una respuesta idónea a los graves problemas que la inmigración masiva actualmente comporta.

Como es sabido el fenómeno migratorio es una constante presente en todo tiempo y lugar. Fenómeno que muda según variables dependientes del ciclo económico, de los índices demográficos, del emporio político, de la distribución internacional de la riqueza, la organización social y de la demanda de mano de obra. En la mente de todos han de estar presentes las migraciones propiciadas por la pobreza, el hambre o la guerra; o la suma todas ellas.

En el plano corto el asunto que traemos a colación parece únicamente concitar aspectos relativos a la política interior y de seguridad del Estado receptor de inmigrantes, con independencia de que los extranjeros dispongan de documentación en regla o no cuenten con ella. Sin embargo, para el análisis preliminar anunciado no debemos olvidar que antes que tales medidas y repercusiones que hemos llamado de corto alcance (interior-seguridad-justicia), la cuestión de la extranjería es un hecho en sentido extenso. Es un fenómeno social e histórico que tradicionalmente ha obligado a los gobiernos de acogida que se veían afectados por ella a adoptar medidas concretas para su tratamiento. A veces medidas atinadas, a veces ciertamente descabelladas. Con todo, soy de la opinión de que el debate de fondo debe versar no tanto sobre los efectos de la inmigración, sino sobre sus causas, puesto que la inmigración como fenómeno masivo es sólo el síntoma de una patología más profunda y que asola al mundo: la tremenda fractura entre la riqueza y la pobreza, entre la prosperidad y la miseria. De ahí que intentar solventar el problema atendiendo sólo a cuestiones jurídicas y policiales es seguramente una estrategia miope y equivocada. Si lo que queremos es tratar la cuestión de la inmigración actual de manera rigurosa, debemos tener en cuenta sus causas y atender a los vínculos entre inmigración y codesarrollo ${ }^{1}$.

${ }^{1}$ Tengamos presente como punto de partida contextual que el promedio del porcentaje del PIB para el desarrollo de los paises de la OECD a favor de los paises menos avanzados es del $0^{\prime} 2 \%$ en lugar del 0'7\% propuesto en 1974. 


\section{ALGUNOS CONCEPTOSY CATEGORIAS ÚTILES}

Junto a ello también debemos barajar categorías $y$ conceptos igualmente actuales que percuten, o deberian hacerlo, sobre los fenómenos migratorios y el consiguiente tratamiento jurídico de la extranjería. Por ello nos vamos a referir a un término relativamente de nuevo cuño que, no obstante, aspira a convertirse en auténtica categoría omnicomprensiva. Se trata del término globalización. Es según su procedencia una expresión de sesgo comercial surgida a impulsos de la mercadotecnia. Expresión oleaginosa dotada de gran fuerza expansiva y bien instalada en el proceder de los estrategas financieros y del management occidental, e indudablemente desarrollada en las operaciones mercantiles de giro internacional. $\mathrm{Me}$ estoy refiriendo a uno de esos sonoros términos que hoy forman parte del lenguaje habitual de políticos y estadistas de diverso pelaje, que con su interlocución creen favorecer su propio discurso. Pese a lo generalizado de su uso sin distinción de ámbitos ni tejidos, sostengo que el término globalización es completamente ajeno al mundo del Derecho. Así para los juristas el término aparece como un extraneus que últimamente se ha tenido que importar e incorporar a nuestra ciencia para no perder el ritmo $y$ potencial que marca la economía neoliberal. Sin embargo y por lo general, se aprecia en los juristas una actitud mucho más cauta en su empleo, hasta el punto de que -en lo posible - nos la solemos ahorrar en evitación de males mayores y de pronunciamientos ajenos a nuestra propia resonancia, eso sí, una vez comprobado que los ordenamientos jurídicos existentes son manifestación de la heterogeneidad cultural $y$, por tanto, tan dispares y divergentes que difícilmente se puede seriamente imaginar la globalización jurídica en los extremos que propone la mercadotecnia supranacional.

No obstante, el término globalización se esgrime en numerosos foros de debate; también en los jurídicos ${ }^{2}$. Aunque debemos insistir - una vez más - en que el vocablo globalización se presenta como un término rudo y extraño para las estructuras jurídicas seculares presentes en los distintos ordenamientos jurídicos. Por tanto, nos interesa conocer qué es lo que se va a globalizar. Nos interesa una explicación clara sobre el contenido y significado de la manoseada globalización. La sola globalización de los mercados financieros y de consumo marcada por su sesgo utilitarista de rentabilidad no es en sí misma panacea de nada, salvo - claro está para los modernos mercaderes y los clásicos especuladores apuntados también a este flamante carro que, por supuesto, están dispuestos a dar por bueno y homologar todo aquello que redunde en el sonido metálico de sus propios dividendos. Por eso quisiera concluir esta incursión dejando adscrito el concepto globalización al terreno puramente económico y crematístico, visto el fracaso que hasta la presente constituye la globalización 
en otras esferas relevantes para la existencia humana universal. De manera que no debe sorprendernos que en buena parte de la doctrina francesa se haya optado por el empleo del término mundialización en lugar de globalización, cuando de lo que se habla es de derechos. Probablemente tan indeseable invasión de la economía supranacional en los dictados de lo jurídico llevó a Federico Mayor Zaragoza a expresar, en una de sus postreras intervenciones públicas (Brasil) como cabeza visible de la UNESCO, que lo que realmente habría que globalizar eran los derechos humanos universales. Ello nos permite afirmar sin ambages que si como primera medida se van a globalizar los derechos humanos fundamentales, entonces podemos seguir incluyendo el término en nuestro acervo. Si lo que se va a globalizar es la referencia ética de los derechos y sus garantías, la referencia ética del respeto y la tolerancia, si lo que se va a globalizar son los medios para vivir y las razones para ello, entonces podemos seguir incluyendo el término globalización entre las convenciones, normas y declaraciones jurídicas. De otro modo y si lo que vamos a globalizar sólo tiene que ver con el afán de lucro y los royalties economicistas que medio mundo obtiene a costa del otro medio, me planto y remito a lo arriba expuesto ${ }^{3}$.

2 Consultar las Actas de las XX Jornadas de la Asociación Española de Profesores de Derecho Internacional y Relaciones Internacionales, "Globalización y Comercio Internacional», Universidad de Jaén, 25 y 26 de septiembre de 2003. En particular la aportación del profesor Juan Manuel FARMIŃÁN GILBERT, titulada "Globalización, sociedad civil y derecho internacional'). Por su sentido crítico consultar el trabajo de Danilo Zolo, "Una crítica realista del globalismo jurídico desde Kant a Kelsen y Habermas ", en Anales de la Cátedra Francisco Suárez, núm. 36, 2002, pág. 216 y ss.

${ }^{3}$ En septiembre de 2003 se ha celebrado en Cancún (México) la cumbre bianual de la Organización Mundial del Comercio (OMC). En la misma, los países pobres y en vías de desarrollo se han "atrevido" a poner en solfa - previo asesoramiento de algunas ONGs como Oxfam - las laudatios que los países ricos, desarrollados e industrializados vienen realizando sobre la nueva oleada de la globalización económica-financiera, (como dato revelador sólo indicar que en esta cumbre de la OMC 2003 estuvieron presentes setecientos miembros de lobbies industriales y agrícolas de EEUU $y$ otros tantos de la UE). Los países ricos, a propuesta de la Unión Europea, han aprovechado la reunión de la OMC en Cancún para propulsar algunos capítulos esenciales para esta nueva oleada globalizadora, a saber: política de inversiones, competencia, transparencia en los contratos públicos y medidas para facilitar el comercio (cfr. Singapur 1996). Estos temas laceran a los países menos desarrollados, que no consideran prioritarios tales asuntos puesto que los obligarian a dispendios presupuestarios y gastos ingentes que como único objetivo tienen la lubrificación del comercio internacional, comprometiendo así los escasos recursos de los países pobres en desembolsos significativos destinados, por ejemplo, a adecuar infraestructuras portuarias $y$ vias de comunicación interna. Operaciones sin duda necesarias, pero que no se cuentan entre las urgencias de los países en vías de desarrollo. Como ha dicho Soledad Gallego-Díaz (vid. El País, 13-9-03, 
Hablando todavia de conceptos generales, otro gran término que quisiera traer a colación y que ha de verse necesariamente implicado en la discusión sobre la extranjería es el concepto ciudadanía, (vid. sobre la creación del estatuto del ciudadano de la Unión Europea: Tratado de Maastricht de 7 de febrero de 1993). El término ciudadanía sí que tiene un claro y clásico entronque jurídico, siendo - por cierto- del todo intrascendente al terreno de la economía. Sin embargo, uno y otro términos, globalización y ciudadania, desde mi punto de vista hasta ahora vocablos extrañados y paralelos, tienen que concitarse en nuestro alegato de hoy porque uno y otro parecen ofrecer respuesta a los planteamientos que sobre la emigración y la extranjería se hacen los ordenamientos jurídicos en la realidad internacional que nos circunda. En la actualidad y con las mínimas matizaciones que preceden, uno y otro término están llamados a ensamblarse puesto que son precisos para contextualizar y dar sentido al reconocimiento $y$ a las garantías de los derechos que corresponden a los extranjeros en nuestro país. Sobre el concepto ciudadanía se están produciendo relevantes actualizaciones que superan la parquedad del vínculo entre el individuo y el Estado al que pertenece. La puesta al día del concepto ciudadanía atañe a su definición jurídica puesto que hasta hace poco ésta sólo se encontraba en los ordenamientos particulares y respecto de su propios nacionales. Sin embargo, de un tiempo a esta parte la noción ciudadano se proyecta sobre un mapa concatenado de innegables referencias internacionales ${ }^{4}$. De hecho, la respuesta de los ordenamientos jurídicos a la nueva y cambiante realidad pasa por el cambio de rumbo hacia un mayor protagonismo de los niveles internacionales en el reconocimiento

pág. 7), si la OMC exige e impone respeto a la competencia comercial, siempre serán las empresas poderosas las que podrán plantear sus demandas mientras que las empresas de los países pobres no dispondrán de medios ni de capacidad para luchar contra las primeras en el mercado que éstas mismas controlan. De ahí que los países desfavorecidos se nieguen a ratificar el compromiso de mantener condiciones estables y predecibles para inversiones transfronterizas, dado que ello representa un atentado contra su soberanía y supone un modo de cortocircuitar el desarrollo equilibrado de sus propias políticas. De ahí los reparos a los que venimos aludiendo tanto en el texto como en la presente anotación, puesto que parece claro que el comercio internacional globalizador es también un escenario en el que se puede ayudar, o perjudicar seriamente, a los países pobres y en vias de desarrollo. Sobre todo si el comercio internacional que se globaliza no se rige por pautas de responsabilidad social, es decir, no integra voluntariamente preocupaciones sociales y medioambientales en sus operaciones mercantiles $y$ en sus relaciones con los interlocutores menos favorecidos.

4 Ana RuBio CASTRo y Mercedes MOYA ESCudero, "Nacionalidad y ciudadanía: una relación a debate", en Anales de la Cátedra Francisco Suárez, núm. 37, 2003, págs. 105 a 153. 
de derechos. De ahí que en este sentido sea necesario enlazar los conceptos globalización y ciudadanía. Baste señalar que en un escenario que nos es próximo, el de la Unión Europea, el ordenamiento comunitario se ha encargado de desbaratar las fronteras de los Estados miembros e internacionalizar las estructuras normativas $y$ sus principios informadores, buscando $-y$ a veces logrando- cierta uniformidad en la aplicación de los derechos. Asi por ejemplo en la Unión Europea aparece reactivado el concepto ciudadanía puesto que define como ciudadano a toda persona que ostente la nacionalidad de un Estado miembro, declara que la ciudadanía de la Unión será complementaria y no sustitutiva de la ciudadanía nacional y reconoce que los ciudadanos de la Unión serán titulares de los derechos y sujetos de los deberes previstos en el ordenamiento comunitario, (art. 17 TA, 1997). Es en este contexto donde adquieren protagonismo las referencias jurídicas supranacionales, $y$ es el contexto en el que me gustaría concitar la combinación de términos y categorías aludidas de globalización y ciudadanía.

\section{DATOSY CIFRAS PARA EL ANÁLISIS}

En cualquier caso hay datos reveladores que en esta aproximación no conviene pasar por alto. Déjenme recordar lo que seguramente ya conocen: En el planeta todavía azul que compartimos son muchos más los países pobres y en vías de desarrollo que los países ricos. Además y pese a todo, en el panorama demográfico mundial se aprecia un continuo incremento de la población, (se han visto sobrepasados los 6000 millones de personas en el año 2000). De hecho, unos 150 millones de habitantes de la Tierra, animados principalmente por razones de naturaleza politica y económica, residen en un país distinto al de origen. Esta tendencia es más que probable que vaya en aumento debido a la mejora de las comunicaciones $y$ por impulso de la denominada sociedad de la información. Pero, sobre todo, son las disparidades económicas y los agravios existentes entre norte y sur, o entre occidente $y$ oriente los que provocan los trasiegos migratorios que estamos tratando. A poca distancia se sitúan otras causas como las derivadas por mor de los conflictos bélicos que surgen por doquier. De manera que bien pudiéramos anunciar que los movimientos demográficos y las corrientes migratorias son fenómenos que están llamados a pronunciarse con mayor contundencia y magnitud en este siglo XXI.

En lo que a España concierne la presión demográfica procede fundamentalmente de su comunidad histórica y de su entorno geográfico más próximo. Así los flujos migratorios que recibe nuestro país proceden bási- 
camente de latinoamérica ${ }^{5}$ - principalmente ecuatorianos y colombianos-, el magreb, la franja subsahariana y, en menor medida, de la Europa del Este, (cfr. anuario Eurostat 2002). Hablando de cifras, no conviene tampoco olvidar que son numerosos los inmigrantes legales que ya viven y trabajan en Europa. Según el anuario Eurostat 2002, en la Unión Europea los inmigrantes legales, documentados o-como se suele decir-compapeles, constituyen aproximadamente el $5 \%$ de la población europea, es decir más de 16 millones de personas. Según el Anuario Estadístico de Extranjería 2002 del Ministerio del Interior, en nuestro país viven 1.448.771 extranjeros con permiso de residencia, es decir, un 3'2 \% de la población total. Y el mismo Anuario indica que el mayor incremento se ha producido en los últimos seis años, período en el que se ha triplicado el número de residentes legales. Las cifras mostradas por Interior evidencian que un $35^{\prime} 56 \%$ son europeos, frente a un $28^{\prime} 75 \%$ procedentes del continente americano; un $27^{\prime} 7 \%$ tienen como origen África y un 7 '9 \% son de procedencia asiática. Para el Ministerio del Interior, en su Anuario Estadístico de Extranjería 2002, los marroquíes son el colectivo mayoritario, con 283.000 personas, $y$ después se sitúan los ecuatorianos, 115.301, y los británicos, 90.091. Siendo Cataluña la Comunidad Autónoma que más extranjeros recibe, seguida de Madrid y Andalucía. Concretamente en España el Instituto Nacional de Estadística difundía en agosto de 2003 que el número de inmigrantes extranjeros empadronados en nuestro país ascendía, a primeros de enero de 2002, a la cifra de 1.977.944, de los cuales sólo 1.109.060 contaba con tarjeta de trabajo o residencia. Estos últimos guarismos nos dan idea bastante aproximada de cuál es el número de inmigrantes legales en España. Entendemos, por tanto, a tales efectos por inmigrantes legales los extranjeros no comunitarios que han fijado su residencia en nuestro país. Sin embargo, hay un dato que difícilmente se puede soslayar. Es el siguiente: en suelo español existe una bolsa de al menos medio millón (500.000) inmigrantes irregulares, que en su mayor parte trabajan en la economía sumergida y que representan en torno al $23 \%$ del producto interior bruto (PIB).

La pregunta está servida, ¿qué hacer con un colectivo tan significativo y creciente que ya está entre nosotros viviendo y trabajando en la clandestinidad?

${ }^{5}$ En cómputo anual las estimaciones apuntan que el flujo continuado de extranjeros a nuestro país se mantendrá en 160.000 por ejercicio. Aunque cabe reseñar que durante el año 2002, como tránsitos en bruto, entraron como turistas en territorio espanol 550.000 ciudadanos latinoamericanos, y sólo abandonaron el territorio nacional en el mismo periplo y concepto 86.000 personas. 


\subsection{Cifras, integración y conflitos.}

En una prospectiva centrada en España las cifras que nos ofrece el Instituto Nacional de Estadística ${ }^{6}$ (INE) son elocuentes por sí solas. Los números cantan que está previsto que para el año 2010 la población extranjera doble a la actual e incluso supere los 4 millones. Es decir, sin tener en cuenta que se registren cambios en la política de visados o en la legislación de extranjería, a finales de 2010 España tendría una población de 46 millones de habitantes de los que 5'5 millones (el $12 \%$ ) serían extranjeros. El mismo estudio oficial contempla que la población extranjera se convertirá en la principal fuente de crecimiento demográfico en el Estado español, (entre el $9 \%$ y el $13^{\prime} 5 \%$ del total del censo).

En Andalucía, con los datos que facilita el INE según el censo del cuarto trimestre del año 2001, el número de extranjeros comunitarios (UE) era de 72.193 , de los cuales aparecen contabilizados 39.178 extranjeros procedentes de América, de África procedían 43.959, de la Europa extracomunitaria procedían 15.582, y se contabilizaron 6.889 como originarios de Asia. El sindicato Comisiones Obreras (CCOO) estima que en la Comunidad Autónoma de Andalucia hay unos 70.000 inmigrantes irregulares del total de 400.000 ó 500.000 que, según la misma fuente, existen en todo el territorio nacional y que aportan más de un $4 \%$ al PIB.

Los datos numéricos y las estimaciones que hemos manejado arrojan más inquietudes si cabe sobre el tema tratado, dado que las previsiones de crecimiento demográfico previstas para España debido a la afluencia masiva de inmigrantes, a la más que probable asimilación pausada de aquéllos y la ralentizada integración social de los extranjeros, van a obligar a las autoridades nacionales a aumentar a ritmo sostenido la inversión pública en infraestructuras de carácter social, tales como viviendas, colegios, centros médicos... De otro modo los efectos perniciosos de tal afluencia redundarán en españoles y extranjeros, porque se habrá producido una considerable rebaja del Estado del bienestar para todos. Ello en sí mismo sería un indeseable multiplicador de conflictos. Pero hemos de reconocer que si la afluencia de inmigrantes es masiva la asimilación pausada no será factible, y si las circunstancias económicas y sociales del país de acogida no son las adecuadas difícilmente se va a producir la integración de los extranjeros en la sociedad. No hay que hacer grandes ejercicios de imaginación para presagiar que en las zonas con mayor presencia de extran-

${ }^{6}$ Estudio monográfico elaborado por Carlos ANGULo para el INE bajo el título La población extranjera en España, Madrid, 2003. 
jeros no asimilados, inadaptados o no integrados, los conflictos aflorarán por doquier, $y$ hasta es posible que la población autóctona quede en minoría en esos lugares. De hecho la concentración de inmigrantes en ciertas áreas del territorio español ya ha generando problemas de convivencia (EI Maresme, El Ejido...). Eso por no hablar de la eventual rivalidad que, a medio plazo, se puede suscitar entre españoles y extranjeros por conseguir un puesto de trabajo. $Y$ si el mercado laboral no puede absorber la mano de obra, se generará paro $y$, como consecuencia, marginación y delincuencia, es decir, más conflictos sociales. Por no hablar de otros problemas, hasta de salubridad, que arrojarían las carencias o imprevisiones de alojamientos adecuados y viviendas sociales para los inmigrantes. En el ámbito sanitario estricto, el Estado y las Comunidades Autónomas deben hacer esfuerzos para evitar que los servicios sanitarios se colapsen en sus respectivos ámbitos. En términos estrictos prestacionales de Seguridad Social y de las pensiones, las autoridades deberían estar atentas a equilibrar la caja en atención al previsible aumento de afiliados, los ingresos por cotizaciones y los gastos por prestaciones derivados de todo ello. Porque los extranjeros, aunque sean legales y coticen a la Seguridad Social, también van al médico, llevan sus hijos al colegio y se convertirán en pensionistas, con los costes nodales y marginales que suponen dichas contingencias $y$ necesidades.

\subsection{Subempleo, economía sumergida y trabajo clandestino.}

Recordemos en este punto los datos facilitados por el Barómetro del Centro de Investigaciones Sociológicas (CIS) a mayo de 2003. Barómetro CIS que señalaba que el. $53 \%$ de los españoles cree que hacen falta trabajadores extranjeros en nuestro pais, siempre que lleguen con contrato, pero que más del $58 \%$ relaciona inmigrantes con inseguridad, y un $68 \%$ considera que se les trata con desprecio $(10 \%)$, agresividad $(17 \%)$, desconfianza $\left(45^{\prime} 5 \%\right)$ o indiferencia $\left(10^{\prime} 6 \%\right)$. De cualquier modo tengamos presente que España es el país de la Unión Europea en el que más ha aumentado la inmigración en los últimos años, gracias en gran parte a la voluminosa regularización efectuada entre los años 2000 y 2002 y a la fuerte demanda de trabajo, cuantificada por los empleadores en una necesidad de 100.000 trabajadores extranjeros al año, aunque las autoridades españolas fijan una cuota que no llega ni a la tercera parte, mientras se lucha con escaso éxito contra los ilegales sin combatir a fondo la opacidad de la economía en la que, por lo general, éstos se sumergen.

Nos conviene registrar también como adelanto los efectos favorables de toda reforma legislativa, y en materia de extranjería conviene poner oído - como más tarde veremos- a si la reciente reforma de la Ley 
de Extranjería española ofrece una solución a los inmigrantes, con y $\sin$ papeles, que sea admisible constitucionalmente.

De entrada modificar el régimen de las sanciones no es un paso cualitativo, sino más bien un paño caliente dependiendo de la óptica en la que nos situemos. Nuestra reciente normativa sobre extranjería no ha dejado de establecer sanciones para los empresarios que utilicen mano de obra extranjera irregular ${ }^{7}$. Lo cierto es que mientras exista una bolsa tan nutrida de trabajadores extranjeros clandestinos, que prácticamente -o mejor dicho oficialmente - no existen como tales trabajadores, los empresarios y empleadores la usarán para abaratar costes con el consiguiente perjuicio para las condiciones laborales, de la contratación $y$, por supuesto, para las prestaciones sociales. De hecho la Comisión Europea considera que en la eurozona la inmigración irregular se ha convertido en el principal acelerador de la economía sumergida en Europa.

Un paliativo podría venir de la mano de una mayor agilidad de la Administración en tanto que diligencie la adecuación y dotación de su acción inspectora en el área laboral ${ }^{8}$. Pero creo que con ello sólo no basta, es necesario anclar en las garantías jurídicas de entronque constitucional y desarrollo legal el amparo que está demandando el inmigrante irregular.

7 Vid. infra, concretamente el epígrafe número 7 de este trabajo, dedicado a la recientísima reforma de la normativa sobre extranjería operada mediante la Ley Orgánica 14/2003, de 20 de noviembre, (BOE núm. 279, viernes 21 noviembre 2003, págs. 41193 a 41204$)$.

${ }^{8}$ Según un reciente balance de la Dirección General de Inspección de Trabajo y Seguridad Social del Ministerio de Trabajo, en el año 2002 se detectaron 8.413 infracciones laborales en las que había inmigrantes implicados. Lo que constituye un $23^{\prime} 5 \%$ más que en el año 2001. Correlativamente y de un año a otro por parte de la Inspección de Trabajo se produjeron un $33 \%$ más de actuaciones en empresas que empleaban mano de obra extranjera irregular.Y en el año 2002 afloraron un total de 63.905 puestos de trabajo en idéntica condición de contratación de subempleo, lo que supone un $3 \%$ más que en 2001.

En este orden de cosas, en fechas recientes el gobierno de la nación ha incorporado una enmienda a la Ley de Acompañamiento de los Presupuestos Generales del Estado para 2004, en cuya virtud decide penalizar a las empresas que empleen inmigrantes en situación administrativa no regularizada como mano de obra sin contrato. De manera que a la sanción que hasta ahora pagaban las sociedades descubiertas por la Inspección de Trabajo en dicha tesitura, se suma el pago de las cotizaciones a la Seguridad Social que el empleador tendría que haber verificado en caso de haber suscrito el inmigrante un contrato regular o normalizado con el inmigrante. El ejecutivo ha previsto que este dinero se ingrese en la TGSS y quede afectado a la atención a inmigrantes. Aunque la novedosa sanción no implicará mutación alguna en la situación del trabajador extranjero, puesto que no se obliga a su alta en la Seguridad Social. 
La concesión enlazada de permiso de trabajo y permiso de residencia puede subvertir está dinámica fraudulenta al tiempo que desmantelaría las. mafias de tráfico de personas.

En definitiva, esta combinación de argumentos dialécticos nos conduce a contemplar la inmigración como un problema de índole socio-económica más que estrictamente político o jurídico.

Ante el reto que supone la integración de los inmigrantes en nuestro modelo social, este creciente fenómeno tiene consecuencias no sólo en el ámbito interno, como luego veremos, sino en el ámbito de las políticas migratorias que inspira la Unión Europea. A nadie se oculta que el carácter restrictivo de la políticas migratorias seguidas por la Unión Europea genera un efecto ignoto hasta hace poco. Me refiero al incremento y desarrollo de las vías ilegales de entrada al territorio de la vieja Europa $y_{\text {, }}$ por supuesto, la proliferación de mafias. $Y$ siendo como es nuestro país frontera exterior de la Unión, ello afecta sobremanera a la normativa interna sobre extranjería que el Reino de España dispone ante tal circunstancia, y que lógicamente se inspira en los criterios propuestos por la Unión Europea tendentes al endurecimiento de la entrada en territorio europeo a los nacionales de terceros países. (Vid. Schengen 1985 y 1990 - define como extranjero a toda aquella persona distinta a los nacionales de los Estados miembros de las Comunidades Europeas; Maastricht 1993 -refiere el estatuto de los nacionales extracomunitarios y contiene una política de visados -; Amsterdam 1997 -instaura definitivamente la vinculación entre la regulación del fenómeno migratorio con la libre circulación de personas sin fronteras interiores-; Tampere 1999 - desarrolla una politica común de la Unión Europea en torno al asilo y la inmigración -; Laeken 2001 - señala la política comunitaria de retorno de los residentes ilegales-; Sevilla 2002 -establece un programa integral comunitario sobre el fenómeno de la inmigración ilegal-). Como puede apreciarse tras el repaso de las referencias aludidas, parece que la Unión Europea está dando pasos significativos para racionalizar la gestión y el control de los flujos migratorios que tienen como destino suelo comunitario. Ahora bien, y sin perjuicio de ello, quizá fuera aconsejable que la Unión Europea buscara el concierto de los países miembros en torno a una concepción clara sobre la integración de los inmigrantes y lai solidaridad. 


\section{EXTRANJERÍAY CIUDADANÍA EN LA UNIÓN EUROPEA}

Llegados a este punto podríamos considerar superada la clásica diferenciación latina entre el derecho de gentes, ius gentium o derecho de extranjeros, y el derecho civil, ius civile o derecho de los ciudadanos ${ }^{9}$. Sin embargo, hemos de retomar alguna de las categorías precedentes puesto que también en nuestros días nos encontramos ante una contraposición palmaria: la que tiene lugar entre ciudadania europea frente a extranjeria en el territorio de la Unión. Desde elTratado de Maastricht, firmado el 7 de febrero de 1993, contamos en Europa con una suerte de estatuto jurídico del ciudadano de la Unión Europea que conlleva un vínculo entre el nacional de los Estados miembros y la propia Unión. A nadie se oculta que esta ciudadanía europea, en tanto que status civitatis, entraña una doble dimensión. Es decir, una dimensión política y una dimensión jurídica. Por su orden esta dualidad se extrae, de un lado, del título de pertenencia de la población a un determinado ente político, $y$, de otra parte, de la cualidad de persona de la que se derivan derechos y obligaciones. Pero como el escenario en el que estamos situados es Europa y hablamos ya de un status de los ciudadanos europeos no se puede admitir a estas alturas la denominación de extranjeros y entre sí para los nacionales de los Estados miembros de la Unión ${ }^{10}$.

9 Para abundar en la idea histórica de sujetos o titulares del Derecho: desde las XII Tablas (mediados del siglo V) podemos hablar en Roma de una organización social, política y jurídica de estructura civica, que gira en torno al ciudadano (civis) como sujeto por excelencia de toda la vida política. Así el civis es el miembro activo de la civitas en cuanto forma parte del populus a través de las curiae, agrupaciones militares y religiosas a la vez de hombres armados. La condición de civis es el fundamento de la capacidad según el ius civile (ius propium civitatis). En Roma se consideraban peregrini a los no ciudadanos que llegaban desde fuera de la civitas y que en época de las XII Tablas eran denominados hostis; reparemos en la etimología de hostil. El peregrinus, ajeno a la civitas, si procedía de una comunidad que tuviese respecto a Roma el ius commercii, podía realizar negocios con romanos mediante la mancipatio, e igualmente tenían reconocido el ius connubii, es decir, que el extranjero o peregrinus podía contraer válido matrimonio en Roma. Cfr. Pablo FuENTESECA, Derecho Privado Romano, Madrid, 1978, págs. 3 a 7.

10 Elisa Pérez Vera, "La ciudadanía europea en el Tratado de Maastricht», en la obra colectiva Hacia un nuevo orden internacional y europeo. Homenaje al profesor Diez de Velasco, Tecnos, Madrid, 1993, pág. 1127 y ss.. A mayor abundamiento la profesora Pérez Vera en su trabajo, "Citoyenneté de l'Unión Européenne, nationalité et condition des étrangers", en $R$. des $C$., 1996, vol. 261, pág. 397. En un análisis actualizado sobre la integración del inmigrante como ciudadano, el trabajo de Ana Rubio Castro y Mercedes Moya Escudero, "Nacionalidad y ciudadanía: una relación a debate », cit., pág. 105 y ss.. 
De manera que estamos en condiciones de concluir, al menos provisionalmente, que con independencia de su pasaporte los ciudadanos europeos se benefician de un principio de igualdad de trato con los nacionales de los Estados miembros, de una movilidad y residencia en el territorio de la Unión Europea, así como de un derecho de sufragio activo y pasivo en las elecciones municipales en el Estado miembro en el que residan.

Luego, ¿qué ha de entenderse por extranjero en territorio de la Unión? Para dar respuesta a esta cuestión debemos acudir a los Acuerdos de Schengen (14 de junio de 1985 y 19 de junio de 1990, respectivamente). En efecto, el segundo de los Acuerdos de Schengen (1990) designa como extranjero a toda persona distinta a los nacionales de los Estados miembros de las Comunidades Europeas. De ahí que a la luz de la normativa comunitaria se podría considerar extranjero con respecto a la Unión el ciudadano no europeo, es decir, el nacional de tercer país o extracomunitario. Luego, tal como dijimos, son ciudadanos de la Unión las personas que ostenten la nacionalidad de un Estado miembro. Por tanto, nos encontramos ante un curioso trinomio que distingue entre el nacional, el europeo y el extracomunitario, que es ciertamente el considerado extranjero. Así, la ciudadanía comunitaria deviene en contador-partidor en el ámbito de aplicación y exclusión de la normativa sobre extranjería, puesto que el destinatario de la normativa orgánica de extranjería no será ya cualquier extranjero, sino especialmente el extranjero inmigrante extracomunitario; es más, con escasos o nulos recursos económicos ${ }^{11}$.

Aquí aparece ya una primera y significativa exclusión puesto que se hace referencia a aquél que carece de la nacionalidad de un Estado miembro $y$, por ende, de la ciudadanía europea. Ello supone que se es extranjero o extraño con relación a una particular comunidad política transnacional que no es otra cosa que un nuevo y relativamente reciente y artificioso ente político, que es la Unión Europea. Lo que conlleva una situación diferencial para el extranjero (extracomunitario) en cuanto al goce de derechos respecto a los propios nacionales o europeos. Es decir, estamos ante una situación diferencial clara para los nacionales de terceros paises ajenos a la Unión Europea. Ello, de entrada, evoca nociones discriminatorias que probablemente el orden constitucional de nuestro país no permita.

${ }^{11}$ Así lo contempla José AsEnSI SABATER en sus Comentarios a la Ley de Extranjería, Zaragoza, 2000, pág. 23. Mencionemos aunque sólo sea de paso que los argumentos clasificatorios que anteceden dejan completamente extinguido el estatuto especial de que venían gozando en España determinados extranjeros que eran nacionales iberoamericanos, de Portugal, de Andorra, de Guinea Ecuatorial, de Filipinas, sefardies y originarios de Gibraltar. 


\section{DERECHOS CONSTITUCIONALES DE LOS EXTRANJEROS}

Desde una perspectiva ciertamente polémica la inmigración tiene, cuando menos, una doble cara, es decir, es a un tiempo problema y solución. Es problema el aumento significativo e imprevisto de inmigrantes en atención a las tensiones relacionales $y$ de convivencia que ello puede desencadenar intra muros. Es solución porque sin esa llegada de inmigrantes la sociedad española difícilmente podría superar graves escollos de futuro debido al paulatino envejecimiento de la población y al preocupante descenso de la natalidad. Motivos de puro pragmatismo unidos a este último dato serían ya, por sí mismos, razón suficiente como para no cerrar las puertas a la inmigración. Pero es que además, aunque quisiéramos, es imposible poner alambradas a la penuria y menos aún al hambre. Estoy convencido de que por más que se construyan murallas o se electrifiquen alambradas, antes o después, el hambre las saltará de todos modos ${ }^{12}$. Por eso creo que haríamos bien en buscar el acuerdo y, si es posible, encontrar el consenso en torno a este tema. Lo que interesa, por tanto, es ofrecer una respuesta sensata y pactada ante lo que debemos contemplar más como un hecho irremediable $y$ creciente que como una adversativa lacra. Para dar cumplida y razonable respuesta al asunto disponemos en primer orden de un Texto constitucional que arroja suficiente luz sobre el tratamiento que merecen los inmigrantes que necesariamente van a arribar a nuestras costas y que la sociedad española está llamada a acoger e integrar ${ }^{13}$.

La Constitución española de 1978 en su artículo 10.1 preceptúa, como principio básico, que la dignidad de la persona, los derechos inviolables que le son inherentes, el libre desarrollo de la personalidad, el respeto a la ley y el respeto a los derechos de los demás son fundamento del orden político y de la paz social. En dicho precepto constitucional, que encabeza el Título I relativo a los derechos y deberes fundamentales, no se hace distinción alguna por razón de la nacionalidad o la situación concreta de regularidad versus irregularidad en que los extranjeros puedan encontrarse en

12 Desde el año 1999 más de 60.000 personas han sido interceptadas en pateras en el Estrecho y en las Islas Canarias.

${ }^{13}$ No perdamos de vista el último inciso de la terminología empleada por la normativa vigente: Ley Orgánica $8 / 2000$, de 22 de diciembre, por la que se reforma la Ley Orgánica 4/2000, de 11 de enero, sobre derechos y libertades de los extranjeros en España y su integración social. (BOE de 1 de junio de 2001). Sin olvidar la reciente Ley Orgánica 14/2003, de 20 de noviembre, que reforma la Ley Orgánica 4/2000, modificada a su vez por la Ley Orgánica $8 / 2000$, de 22 de diciembre, y que trataremos más adelante por su especificidad y urgente incorporación a nuestro ordenamiento jurídico en el BOE del viernes 21 de noviembre de 2003. 
España. Es más, el artículo 10.2 de la Constitución añade pautas interpretativas e integradoras, por si hubiera dudas, en torno a la exégesis del artículo 10.1, de manera que las normas relativas a los derechos fundamentales y a las libertades que la Constitución reconoce, se interpretarán de conformidad con la Declaración Universal de Derechos Humanos y los tratados y acuerdos internacionales sobre las mismas materias ratificados por España ${ }^{14}$. Partiendo de ello debemos dejar sentado que los extranjeros han de ser tratados con la consideración debida a su condición de personas, sea cual sea la situación administrativa en la que se encuentren en España.

Decimos esto tras constatar que la inmigración en sí misma es una fuente de discriminación entre nacionales y extranjeros; en unos casos por motivos étnicos, religiosos, laborales, $y$, entre otros supuestos la discriminación afecta directamente a la participación social y política. De ahí que el tratamiento constitucional y la regulación legal del status de los extranjeros inmigrantes es decisiva para la integración de los mismos, puesto que el Derecho, y en particular el Derecho que dimana de la Constitución, es un instrumento básico que nos aproxima a alcanzar el objetivo de aplacar, atemperar $y$, si se puede, erradicar el potencial discriminador que lo desconocido y diverso casi siempre comporta. Discriminación que a poco que se escarbe encontraremos lastrada por atavismos de diversa índole y por el miedo elemental.

Dentro del Capítulo I del Título I de nuestra Constitución, dedicado a los españoles y a los extranjeros, el artículo 13.1 señala que los extranjeros gozarán en España de las libertades públicas que se garantizan en dicho Título, según se establece en los tratados internacionales de los que España sea parte y según nuestras propias leyes. La única exclusión explí-

${ }^{14}$ En concreto: Declaración Universal de Derechos Humanos adoptada y proclamada por la Asamblea General de la ONU el 10 de diciembre de 1948. Instrumento de ratificación del Convenio para la protección de los Derechos Humanos y de las Libertades Fundamentales, suscrito en Roma el 4 de noviembre de 1950 y enmendado por los Protocolos adicionales números 3 y 5 de 6 de mayo de 1963 y 20 de enero de 1966, respectivamente (BOE de 10 de octubre de 1979). Por Instrumento de 28 de noviembre de 1996 se ha ratificado el Protocolo núm. 11 de 11 de mayo de 1994, que modifica sustancialmente el Convenio Europeo de Derechos Humanos. Instrumento de ratificación por España del Pacto Internacional de Derechos Civiles y Políticos, Nueva York, 19 de diciembre de 1966 (BOE de 30 de abril de 1977). Instrumento de ratificación por España del Pacto Internacional de Derechos Económicos, Sociales y Culturales, Nueva York, 19 de diciembre de 1966 (BOE de 30 de abril de 1977). Instrumento de ratificación de 29 de abril de 1980, de la Carta Social Europea, hecha en.Turín el 18 de octubre de 1961 (BOE de 26 de junio y 11 de agosto de 1980). Ley Orgánica 6/2000, de 4 de octubre por la que se autoriza la ratificación por España del Estatuto de la Corte Penal Internacional. 
cita que contiene el artículo 13 de la Constitución se contiene en el apartado segundo de dicho precepto, cuando indica que solamente los españoles serán titulares de los derechos reconocidos en el artículo 23 (derecho fundamental a participar en los asuntos públicos, participación política y de acceso a los cargos públicos). Queda a salvo, en este punto, la participación política de los extranjeros en las elecciones municipales, en cuyo caso podrán contar con el derecho de sufragio activo y pasivo atendiendo a criterios de reciprocidad, tratado o ley aplicable, (art. 13.2 in fine).

Apoyados en los artículos 10.2 y 13.1 de la Constitución podemos afirmar que en nuestro país el extranjero es destinatario inmediato de las libertades delTítulo I de la Constitución, aunque su ejercicio se transfiera a niveles normativos de rango inferior (leyes, tratados) ${ }^{15}$. Luego para garantizar las libertades del Título I en relación con el artículo 13.1 de la Constitución es preciso acudir, cualquiera que sea la interpretación, al verdadero alcance y sentido que proporciona la inserción del artículo 13.1 en elTítulo I de nuestro Texto Básico. De manera que no deben correrse riesgos de constitucionalidad por parte de las leyes que eventualmente modulen el ejercicio de estos derechos y libertades sin respetar el contenido esencial de tales derechos y libertades. En cualquier caso, si la ley se produjera en perjuicio o empañando el contenido esencial de las libertades y derechos de los extranjeros, inmediatamente saldrían al paso de dichos postulados legales de dudosa constitucionalidad tanto el artículo 10.2 de la propia Constitución como los tratados y convenios internacionales suscritos por España.

Considero que los anteriores preceptos constitucionales son suficientemente claros. No obstante, las decisiones del Tribunal

${ }^{15}$ Como ha indicado Elena PÉrEz MARTín, ahi se sostiene el recurso de inconstitucionalidad planteado por un grupo de diputados (G. P. PSOE, Madrid, 23 de marzo de 2001) de conformidad con los arts. 161.1.a) y 162.1.a) cuando señala que la exigencia de autorización de estancia o residencia en España para el ejercicio de determinados derechos (reunión, manifestación, asociación, tutela judicial efectiva y sindicación) supone una vulneración de los mandatos de la Constitución. Lo que sería así porque la fórmula que nos plantea el legislador para limitar el ejercicio de derechos es diabólica. Admitiendo que el goce de un derecho y su ejercicio se corresponden con dos esferas diversas -el primero a la capacidad que posee el sujeto para ostentar la titularidad del derecho, $y$ el segundo, a la capacidad de hacer efectivo en la realidad ese derecho concreto-. Siguiendo este criterio, puede reconocerse a un extranjero el goce de un derecho $y$, sin embargo que quede limitado su ejercicio a lo que prevean los tratados y la ley. De manera que el goce de las libertades y derechos suele reconocerse de forma amplia, como una esfera mayor dentro de la cual vendría incluido el ámbito del ejercicio de los mismos que puede estar sujeto a limitaciones o al cumplimiento de ciertos requisitos como la estancia legal en España. (Vid. Elena Pérez MARTín, "Los derechos de los extranjeros en España: el derecho al trabajo y las libertades políticas conexas, el derecho de sindicación y el de huelgan, en la Revista del Poder Judicial, núm. 68, cuatro trimestre 2002, pág. 27, nota 22). 
Constitucional español han arrojado luz jurisprudencial sobre dicha materia. Así se condensa en la STC 95/2000, de 10 de abril, en cuanto al alcance de la proyección del principio de igualdad y no discriminación sobre los derechos y libertades de los extranjeros del artículo 13.1 de la Constitución, trato igualitario sólo condicionado a lo que establezcan los tratados y la ley. No en vano ya desde la STC 107/1984, de 23 de noviembre, el Alto Tribunal mantiene que ni la expresión misma de libertades públicas ha de interpretarse en sentido restrictivo, ni tal remisión supone que se haya querido desconstitucionalizar la posición jurídica de los extranjeros relativa a ellas, sino que supone, únicamente, el reconocimiento de éstas con arreglo a su configuración legal. Para comprender con toda su potencia lo que el Tribunal Constitucional expresa sigamos la lectura efectuada por la STC 107/1984. Es decir, la Constitución no dice que los extranjeros gozarán en España de los derechos y libertades que les atribuyan los tratados y las leyes, sino que los extranjeros gozarán de las libertades y derechos que garantiza el Título I de la Constitución (derechos y deberes fundamentales) en los términos que establezcan los tratados $y$ la ley. De modo que los derechos y libertades reconocidos a los extranjeros siguen siendo derechos constitucionales $y$, por tanto, dotados - dentro de su específica regulación- de la protección constitucional, eso sí, en cuanto a su contenido todos esos derechos están precisados de configuración legal o, dicho de otro modo, necesitados de desarrollo normativo específico. En ese sentido leemos una completa igualdad entre españoles y extranjeros, en particular en lo que atañe a aquellos derechos que son imprescindibles para la garantía de la dignidad humana; donde sí que no caben distingos en torno a la nacionalidad o ciudadanía del titular, según dispone el artículo $10 \mathrm{CE}$ (vida, integridad física y moral, intimidad, libertad ideológica...).

Argumentos como los que preceden nos facilitan una lectura coordinada de los artículos 13 y 14 de la Constitución que incide en la proclama constitucional de la igualdad, eso sí, ya atribuida sin paliativos a los extranjeros en España. De modo que éstos adquieren un estatuto directo y positivo que supone la titularidad, el goce y ejercicio de un núcleo de derechos $y$ libertades que no admiten degradación legislativa dependiente de las coyunturas. Como se ha indicado recientemente ${ }^{16}$, la posición jurídica del extranjero responde a su consideración como destinatario directo de los derechos fundamentales que la Constitución declara y garantiza. Siendo así que la consideración de extranjero en este momento carece de relevancia

16 E. PÉrez Martín, «Los derechos de los extranjeros en España: el derecho al trabajo y las libertades políticas conexas, el derecho de sindicación y el de huelga», cit. pág. 30. 
jurídica puesto que la propia Constitución establece un punto de partida común para nacionales y extranjeros. Cuando se procede a desarrollar mediante normas las libertades o los derechos fundamentales es cuando interviene el carácter heterogéneo al sistema que representa la extranjería del sujeto titular del derecho. De ahí que entre la plenitud o la asimilación total al régimen del ciudadano y el límite mínimo impuesto por el núcleo esencial de un concreto derecho o libertad, deben existir diferencias de tratamiento jurídico determinadas por el concepto de igualdad que traduce el artículo 14 de la Constitución en su versión igualdad en la ley; no ante la ley.

En definitiva, una cosa es autorizar diferencias de tratamiento entre españoles y extranjeros, y otra bien distinta entender dicha autorización como un cheque en blanco que representa la posibilidad de legislar al respecto sin tener en cuenta los mandatos constitucionales ${ }^{17}$.

\subsection{Al menos tres grandes grupos de derechos constitucionales vinculados a la extranjería.}

Así podemos hablar de:

a) Derechos que corresponden por igual a españoles y extranjeros, con independencia del factor regularización.

b) Derechos exclusivos de los nacionales españoles y de los que están privados los extranjeros.

c) Derechos reconocidos a los extranjeros según condiciones contenidas en los tratados $y$ las leyes.

a) En cuanto al primer grupo, los extranjeros gozan en nuestro país de todos aquellos derechos que pertenecen a la condición de persona en cuanto tal y que resultan imprescindibles para la garantia de la dignidad humana, (art. $10.1 \mathrm{CE})^{18}$. En este grupo de derechos no cabe diferenciación alguna entre personas. (Derecho a la vida, art. 15; derecho a la libertad ideológica, religiosa y de culto, art. 16; derecho a la libertad personal, art. 17; derecho al honor, a la intimidad personal y familiar, y a la propia

17 Argumento esgrimido por el Tribunal Constitucional en el tercer razonamiento jurídico de su STC 115/1987.

${ }^{18}$ Sobre la particular impronta o aliento racionalista, dogmático y universalista de este grupo de derechos, vid. el libro de AntonioToREs DEL MORAL, Introducción al Derecho Constitucional, Servicio de Publicaciones Facultad de Derecho, Universidad Complutense, Madrid, 1996, págs. 133 a 147. 
imagen, a la inviolabilidad del domicilio, al secreto de las comunicaciones, art. 18; libertad deambulatoria, art. 19, si bien buena parte de la doctrina admite que las libertades de circulación y residencia no son privativas de los nacionales, el art. 19 de la Constitución señala a los españoles como titulares del derecho a elegir libremente su residencia y a circular por el territorio nacional, de manera que nos encontramos ante un caso en que la Constitución española no contempla, pero tampoco prohibe, la titularidad por parte de los extranjeros de un derecho fundamental, por lo que habrá que estar, a tenor de lo preceptuado en el art. 13, a lo que establezcan los tratados y las leyes, (vid. en sentido restrictivo de este catálogo, el tercer grupo de derechos que subsigue); el derecho de expresión en cualquiera de sus manifestaciones, art. 20; el derecho de reunión y manifestación, art. 21, (vid. en sentido restrictivo de este catálogo, el tercer grupo de derechos que subsigue); derecho de asociación, art. 22, (vid. en sentido restrictivo de este catálogo, el tercer grupo de derechos que subsigue); derecho a obtener la tutela judicial efectiva, art. 24; derecho a la educación básica gratuita y obligatoria, art. 27; derechos de sindicación y huelga, art. 28, también sujetos a notoria discusión). Debemos decir a este respecto que el Tribunal Constitucional no ha tasado el número de derechos fundamentales y libertades públicas en los que existe una completa igualdad entre españoles y extranjeros, sino que se limita a efectuar una enunciación ilustrativa.

b) El segundo grupo de derechos constitucionales y que están sustraídos a la titularidad de los extranjeros en nuestro país, son-los derechos de participación política - directa o indirecta - y acceso a los cargos públicos. Estos derechos se encuentran reconocidos en el artículo $23 \mathrm{CE}$, aunque en su matización debamos acudir a lo dispuesto en el artículo 13.2 CE en atención a criterios de reciprocidad para el derecho de sufragio activo y pasivo en las elecciones municipales. Estos derechos están íntimamente vinculados a la ciudadanía española y europea. Este grupo de derechos tabica y diferencia de manera neta entre nacionales y extranjeros. En este punto conviene reseñar que los ciudadanos comunitarios quedan equiparados en determinados aspectos a los propios nacionales ${ }^{19}$. En relación con este grupo excluyente de derechos se viene indicando por

19 Argumento esgrimido por el Tribunal Constitucional en el tercer razonamiento jurídico de su STC 115/1987. 
la doctrina ${ }^{20}$ que por tratarse de derechos no configurados para su titularidad al alcance de los extranjeros, las situaciones jurídicas de los extranjeros en relación con ellos aparecen como bienes juridicos a proteger, es decir, como intereses sociales dignos de protección jurídica, cuya juridificación puede adoptar diversas manifestaciones, salvo la de derechos fundamentales. Por ello las situaciones jurídicas de los extranjeros derivadas de los mismos aparecen, a su vez, como bienes jurídicos disponibles en el marco de las distintas políticas públicas relativas a la inmigración, el empleo u otras, en el marco de sus respectivas competencias.

c) El tercer grupo de derechos constitucionales que compromete el estatuto juridico de los extranjeros en España es el integrado por aquellos derechos mediatizados o condicionados en su titularidad o ejercicio, según lo que establezcan las leyes y los convenios internacionales. Este grupo señala diferencias circunstanciales entre extranjeros y nacionales en razón de ciertas pautas. Tales pautas las encontramos normativizadas en la vigente Ley de Extranjería (Ley Orgánica 8/2000, de 22 de diciembre, por la que se reforma la Ley Orgánica 4/2000, de 11 de enero, sobre derechos y libertades de los extranjeros en España y su integración social). La normativa orgánica ha mudado en sus principios inspiradores hacia cierta restricción puesto que la L.O. 8/2000 incide en la regulación de los derechos de los extranjeros $y$ en concreto en los derechos que se podrian denominar socioeconómicos, ahora sólo reconocidos a los extranjeros que se encuentren con residencia o estancia legal en España, (art. 3 de la L.O. 8/2000). Dicha normativa orgánica dispone ahora que los extranjeros gozarán en España de los derechos y libertades reconocidos en elTítulo I de la Constitución en los términos establecidos en los tratados internacionales, en la propia L.O. 8/2000 y en las demás leyes que regulen el ejercicio de cada uno de ellos y que como criterio interpretativo general, se entenderá que los extranjeros ejercitan los derechos que les reconoce la L.0.8/2000 en condiciones de igualdad con los españoles. En este tercer grupo de derechos reconocidos a los

${ }^{20}$ Sobre la particular impronta o aliento racionalista, dogmático y universalista de este grupo de derechos, vid. el libro de Antonio TORES DEL MORAL, Introducción al Derecho Constitucional, Servicio de Publicaciones Facultad de Derecho, Universidad Complutense, Madrid, 1996, págs. 133 a 147. 
extranjeros regularizados se situan: el derecho a la libre circulación por el territorio español y fijación libre de residencia; los derechos de reunión, manifestación y asociación; el derecho a la educación no obligatoria; el derecho al desempeño de actividades de carácter docente o de investigación científica; derecho al trabajo en el ámbito público y privado y el derecho a la seguridad social; las libertades de sindicación y huelga; el derecho a la vivienda y el acceso al sistema público de ayudas en materia de vivienda; los derechos prestacionales en materia de seguridad social ante situaciones de necesidad; el derecho a la vida familiar y a la reagrupación ${ }^{21}$ de la familia nuclear (cónyuge del residente, hijos del residente y del cónyuge, incluidos los adoptados siempre que sean menores de dieciocho años o estén incapacitados, menores de dieciocho años o incapaces cuando la persona residente sea su representante legal, ascendientes de la persona reagrupante o su cónyuge, cuando se encuentren a su cargo y existan razones de necesidad).

De estos tres grupos de derechos, a efectos constitucionales estrictos, los que más interesan son los primeros, es decir, aquéllos que corresponden por igual a españoles y extranjeros. Se trata de derechos y libertades constitucionales incondicionales, que no diferencian nacionalidades ni situaciones derivadas de las regularizaciones administrativas. Derechos, en definitiva, que consideramos imprescindibles para la garantia de la dignidad humana y que no aparecen articulados en la legislación orgánica sobre extranjería.

Efectivamente, son derechos y libertades fundamentales que por igual corresponden a españoles y extranjeros sin más distinción los que hemos encuadrado en el primer grupo. Sin embargo, en ese grupo hemos recogido también una serie de derechos $y$ libertades discutibles doctrinalmente y que el tenor de la legalidad vigente sitúa fuera del encaje inicial para incluirlos en el tercer grupo, es decir, en el grupo de los derechos reconocidos a los extranjeros según condiciones contenidas en los tratados y las leyes. Estos no son otros que el derecho a la libre circulación por el territorio español y la libertad de fijación de libre residencia; los derechos de reunión, manifestación y asociación.

21 Sobre el derecho a la reagrupación familiar el trabajo de Mercedes MoYA Escudero, "Derecho a la reagrupación familiar", Comentario sistemático a la Ley de extranjería (LO 4/2000 y LO 8/2000), Comares, Granada, 2001, págs. 673 a 707. 
Un examen mínimamente desglosado del primer grupo de derechos y libertades constitucionales al que hemos hecho alusión más arriba nos obliga a reparar en lo obvio: se trata de derechos y libertades no regulados nominativamente en la legislación orgánica de extranjería. Seguramente es comprensible la omisión legal puesto que sabemos que tales derechos son cruciales, esenciales e imprescindibles para la garantía de la dignidad humana (arts. 10.1 y $13.1 \mathrm{CE}$, en relación con el art. 3 de la LOEX). Creo que estamos en condiciones de afirmar que es pacífico el acuerdo en torno a que, al margen de su concreta situación regular o irregular en España, los extranjeros son igualmente titulares de tales derechos y libertades.

\subsection{Desglose}

Desglose del grupo primero de derechos y libertades constitucionales:

El derecho a la vida y a la integridad física y moral, (ex art. $15 \mathrm{CE}$ ), (SSTC 107/1984).

Libertad ideológica, religiosa y de culto, (art. $16 \mathrm{CE}$ ). Y cuyo único límite se encuentra en la preservación del orden público, (STC 107/1984).

Derecho a la libertad personal y a la seguridad, (ex art. 17 CE), (SSTC $107 / 1984,115 / 1987$ y 169/2001).

Derecho al honor, intimidad personal, (ex primer inciso del art. 18 CE). No así la intimidad familiar, que aparece regulada en la Ley Orgánica de Extranjeria 8/2000, (arts. 16 a 19 LOEX). (SSTC 107/1984, 176/1995 y 13/2001).

Libertad de expresión y libertad de opinión, (ex art. $20 \mathrm{CE}$ ).

Principio de legalidad sancionatoria tanto en materia penal como administrativa, lex arts. 9.3 y $25.1 \mathrm{CE}$, en relación con los arts. 50 a 67 LOEX para las infracciones y sanciones administrativas).

Derecho a la tutela judicial efectiva, (ex art. 24 CE), (STC 99/1985).

Derecho de los reclusos a un trabajo remunerado $y$ a los beneficios correspondientes a la Seguridad Social, (ex art. 25.2 CE, en relación con la arts. 27 y 33 de la Ley Orgánica General Penitenciaria, y los arts. 132 a 153 del Reglamento Penitenciario, en relación con los beneficios de la Seguridad Social los arts. 35 de la LOGP y art. 134.7 del Reglamento Penitenciario, sobre la asistencia sanitaria el art. 4.2.a) de la LOGP y los art. 207 a 220 del Reglamento Penitenciario). 
Derecho a contraer matrimonio, (ex art. $32 \mathrm{CE}$ ), (SSTC 207/1996 y 169/2001).

Derecho a la propiedad privada y a la herencia, (ex art. $33 \mathrm{CE}$ ).

Conviene advertir que los tres últimos derechos reseñados no son en sentido estricto derechos fundamentales, sino derechos constitucionales ligados a la dignidad de la persona y al carácter incondicional con que se predican su titularidad, efectos y ejercicio. En todo caso, el artículo 13 de la Constitución establece que los extranjeros gozarán en España de las libertades públicas que garantiza elTítulo len los términos que marquen los tratados y la ley. De manera que los tratados y las leyes podrán concretar las peculiaridades del ejercicio de los derechos cuando su titularidad recaiga sobre personas extranjeras. Pero, tal regulación solamente podrá contener el régimen de ejercicio de los derechos, sin excluir titularidades ni restringir el ámbito constitucional de los mismos de forma que haga impracticable su ejercicio a los extranjeros ${ }^{22}$. En la misma lógica se expresa el Tribunal Constitucional cuando señala que la autorización que el artículo 13.1 de la Constitución confiere al legislador para establecer restricciones y limitaciones a los derechos fundamentales y las libertades públicas de los extranjeros en España no es ilimitada ${ }^{23}$.

\section{NORMATIVA SOBRE EXTRANJERIAYY SUS REFORMAS}

Siguiendo con lo inmediato y por lo que podríamos denominar cuestiones de bulto, no creo necesario recordar que el objeto de este rápido análisis se ocupa de tratar de averiguar si el actual tratamiento jurídico y legal de la extranjería es constitucionalmente el adecuado, es decir, si contempla la integración de los inmigrantes en el país de acogida. El sentido y tenor de la normativa sobre extranjería puede ser decisiva para garantizar un trato cabal (legítimo y legal) e igualitario a todas las personas que, con independencia de su origen, cohabiten en nuestro país.

22 La separación entre titularidad de los derechos y ejercicio de los mismos es una aporia de difícil engaste constitucional que ha operado como presupuesto de algunos de los recursos de inconstitucionalidad planteados contra la L.O. 8/2000. La Ley impugnada parte de la separación entre titularidad y ejercicio de los derechos con el objeto de impedir lo segundo hasta tanto no se cuente con la correspondiente autorización administrativa de estancia o residencia.

${ }^{23}$ Fundamento Jurídico $2^{\circ}$ de la STC 99/1985, de 30 de septiembre. Fundamento Jurídico $6^{\circ}$ de la STC 254/1993, de 20 de julio, y Fundamento Jurídico $3^{\circ}$ de la STC 292/2000, de 30 de noviembre. 
Recordemos que el artículo 10.1 de la Constitución española de 1978 preceptúa como principio básico que la dignidad de la persona, los derechos inviolables que le son inherentes, el libre desarrollo de la personalidad, el respeto a la ley y a los derechos de los demás son fundamento del orden político y de la paz social. En dicho precepto constitucional, que encabeza el Título I relativo a los derechos y deberes fundamentales, no se hace distinción alguna por razón de la nacionalidad o la situación concreta de regularidad versus irregularidad en que los extranjeros puedan encontrarse en España. Es más, el artículo $\mathbf{1 0 . 2}$ de la Constitución añade pautas interpretativas e integradoras por si hubiera dudas en torno a la exégesis del artículo 10.1, de manera que las normas relativas a los derechos fundamentales $y$ a las libertades que la Constitución reconoce, se interpretarán de conformidad con la Declaración Universal de Derechos Humanos y los tratados y acuerdos internacionales sobre las mismas materias ratificados por España ${ }^{24}$.

De entrada podemos afirmar que frente a la Ley Orgánica 7/1985, la Ley Orgánica 4/2000 pretendió la máxima equiparación de los nacionales y extranjeros y de éstos entre sí, con independencia de las circunstancias de su residencia, visto que la Ley de 1985 propugnaba la necesidad de diferenciar con absoluta claridad las situaciones de legalidad de las de ilegalidad.

¿A quién se escapan ya a estas alturas de los debates sociales, políticos y parlamentarios las diferencias existentes entre la Ley Orgánica 4/2000, de 11 enero, sobre derechos y libertades de los extranjeros en España y su integración social, y dicha Ley tras la reforma operada por la Ley Orgánica 8/2000, de 22 de diciembre?

Es palmario que la original Ley de Extranjeria (L.O. 4/2000) fue el resultado de una proposición de ley, esto es, de una iniciativa legislativa parlamentaria y no gubernamental. Ello supuso beneficios impagables para una norma juridica tales como el acuerdo plenario de todos los grupos parlamentarios, traducido en la aprobación unánime del texto legal por el Congreso de los Diputados. Asi nos encontramos con una norma, la Ley Orgánica 4/2000, que mejoraba notablemente el tratamiento de los derechos de los extranjeros y obedecía a unos objetivos mucho más amplios que los propuestos por la Ley de Extranjería de $1985^{25}$. Pero la euforia parlamentaria que alumbró la Ley de Extranjería 4/2000 no iba a durar, vién-

24 Téngase presente la normativa internacional citada a pie en el epigrafe anterior.

${ }^{25}$ Es sabido que la Ley Orgánica 7/1985 era una norma orientada principalmente a regular los requisitos $y$ exigencias de entrada, residencia, trabajo y expulsión de los extranjeros. 
dose asi frustrada su pretensión de establecer condiciones para que los extranjeros se estableciesen en nuestro país accediendo al trabajo y a la residencia y equiparando, prácticamente, a efectos constitucionales a españoles y extranjeros en materia de derechos y libertades ${ }^{26}$. La mayoria absoluta lograda por el Partido Popular en las elecciones generales del 2000 iba a producir mutaciones sensibles en dicha norma jurídica de rango legal, propiciando así la reforma operada por la Ley Orgánica $8 / 2000$, de 22 de diciembre. El argumento subyacente que el gobierno de la nación hizo valer para justificar la modificación legislativa a tan corta distancia de su inicial redacción, se apoyaba en que el ejecutivo de la nación consideraba que la Ley $4 / 2000$, aprobada en abril de 2000 , generaría el "efecto llamada" hacia potenciales inmigrantes, y ello haría inmanejable la cuestión de la inmigración.

La traducción jurídica de todo ello se plasmó en el la Ley Orgánica $8 / 2000$, que frente a la Ley $4 / 2000$, supuso ${ }^{27}$ :

- Que los extranjeros en situación irregular sólo tendrían derecho a la asistencia sanitaria y a la educación obligatoria. Los demás derechos (reunión, asociación, participación, sindicación y huelga) quedan reservados a los que se encuentren en situación legal (autorización de estancia o residencia).

- Que si bien con la anterior legislación la denegación del visado debía ser expresa, motivada y con indicación de las posibles vías de impugnación de la misma, ahora la denegación sólo tendrá que ser motivada cuando se trate de visados para residentes por reagrupamiento familiar y para trabajadores por cuenta ajena.

- Que se eleva de dos a cinco años el tiempo de estancia en España para obtener temporalmente permiso de residencia.

- Que se restringe el ámbito de familiares susceptibles de alcanzar el reagrupamiento familiar.

26 Juan CANo Bueso, "Los derechos de los extranjeros en España: una perspectiva constitucional», cit., pág. 19. Como el propio autor citado indica, las conclusiones adoptadas por los Jefes de Estado y Gobierno de los Estados miembros de la Unión Europea, celebrada en Tampere los días 16 y 17 de octubre de 1999, a fin de crear un espacio de libertad, seguridad y justicia, suministraron los argumentos políticos para abordar la reforma de la Ley Orgánica 4/2000, reguladora de los derechos y libertades de los extranjeros en España y su integración social. Por su valor argumental extensivo conviene consultar la obra de José RuBIo CARRACEdo, Ciudadania, nacionalismo y derechos humanos, (ciudadanía compleja y democracia), Trotta, Madrid, 2000, pág. 28 y ss..

27 Comparto el criterio que Juan CANO BuESo expone en su trabajo "Los derechos de los extranjeros en España: una perspectiva constitucional", cit., pág. 20. 
- Que en materia de expulsiones, el extranjero que se encuentre en situación irregular por carecer de permiso, tenerlo caducado por más de tres meses o trabajar sin autorización, es causa suficiente de expulsión en cuarenta y ocho horas y mediante un procedimiento urgente.

- Que en materia de garantías, la tutela judicial efectiva que teóricamente corresponde a todos los extranjeros sin distinción, se ve imposibilitada de producir efectos ante la inminencia de un procedimiento de expulsión tan expeditivo como el que hemos reseñado anteriormente. Idéntica restricción que afecta a las garantías jurisdiccionales se puede apreciar en la Ley Orgánica 8/2000, puesto que únicamente tendrán acceso a letrado de oficio y justicia gratuita los inmigrantes que ya se encuentren en territorio español.

De cualquier modo la vigente Ley de Extranjería afecta al régimen constitucional de los extranjeros en España recogiendo quince derechos y libertades de los mismos, de los cuales cuatro carecen de rango de norma orgánica. Así en su engranaje normativo la Ley de Extranjería contiene en su artículo 10 los derechos relativos al derecho al trabajo y la Seguridad Social; en el artículo 12, el derecho a la asistencia sanitaria; en el artículo 13 , las ayudas en materia de vivienda; en el 14, el derecho a la Seguridad Social y a los servicios sociales. Y curiosamente, en el artículo 4 la Ley en vigor reitera ${ }^{28}$ la obligación de documentación sobre su identidad y el hecho de hallarse en suelo español y que comprende a los extranjeros. Únicamente un comentario sobre el artículo 16 de la Ley del 2000 sobre el derecho a la reagrupación familiar, que encuentra acomodo en los artículos 32 y 39 de la Constitución (derecho al matrimonio y protección social, económica y jurídica de la familia), y no tanto en el artículo 18 del Texto Básico como se desprende de la Ley vigente.

De nuevo nos encontramos con que se problematiza el hecho antes que arbitrar mecanismos de encaje e integración de los ciertos y/o eventuales inmigrantes instalados en nuestro país. Aspecto este último en el que seguramente era igualmente perfectible el texto legal que ahora se reformaba (diciembre de 2000). En septiembre pasado (2003) hemos asistido a un acuerdo sobre inmigración entre el gobierno y el primer partido de la oposición, acuerdo que puede desencadenar la tercera reforma de la

${ }^{28}$ Ya lo establece con carácter general el art. 11 de la Lèy Orgánica 1/1992, de protección de la seguridad ciudadana. 
Ley de Extranjería en tres años, esta vez con el aparente consenso de los dos grandes partidos nacionales (PP y PSOE) ${ }^{29}$. Lo cual no deja de llamar la atención vista la persistencia del partido en la oposición en mantener el recurso de inconstitucionalidad que tiene interpuesto ante el Alto Tribunal contra la Ley actualmente en vigor. Creemos, por tanto, que estamos en presencia de una teatralización o concierto parcial y limitado a algunos aspectos relacionados con la extranjería en línea con lo que propone la Unión Europea, pero que no se trata de un pacto de Estado sobre la totalidad de la política de inmigración. Más aún cuando el recurso planteado contra la anterior reforma de la Ley de Extranjeria y mantenido por la oposición cuestiona e impugna el recorte de derechos impuesto por la misma a los inmigrantes irregulares (entre otros los derechos de asociación $y$ manifestación, concretamente el recurso de inconstitucionalidad planteado por un grupo de diputados del Grupo parlamentario Socialista accionó con fecha 23 de marzo de 2001 y de conformidad con lo señalado en los artículos 161.1.a) y 162.1.a) de la Constitución, cuando establece que la exigencia de autorización de estancia o residencia en España para el ejercicio de determinados derechos - reunión, manifestación, asociación, tutela judicial efectiva y sindicación - supone una vulneración de los mandatos de la Constitución. Parece ajustado sostener que la facultad de ejercicio de los derechos es inherente a las libertades de reunión, manifestación, asociación, sindicación y huelga, de manera que la privación de dicho ejercicio equivale a la negación de la titularidad del derecho o la libertad de que se trate. De otro modo se produciría el desconocimiento del contenido esencial del derecho fundamental, como límite insoslayable para el legislador, desde el momento en que el derecho fundamental deja de ser reconocible como tal, o queda sometido a limitaciones que lo hacen impracticable, lo dificultan más allá de lo razonable o lo despojan de la necesaria protección ${ }^{30}$ ). De hecho la base del actual acuerdo entre PP y PSOE se centra en la lucha contra la inmigración irregular y en canalizar debidamente a los inmigrantes llamados legales. Los hitos principales de dicho acuerdo sobre inmigración entre gobierno y oposición son:

29 El acuerdo quedó ratificado por ambas fuerzas parlamentarias el 13 de septiembre de 2003 en la ponencia Constitucional del Congreso de los Diputados. No obstante, haber prescindido en el referido consenso para la reciente reforma de la Ley de Extranjería de los demás grupos parlamentarios ha dado lugar a cierta polémica. Vid. la opinión de Javier Pérez Royo, en el diario El País (edición de Andalucia), domingo 14 de septiembre de 2003, pág. 2.

30 Juan B. CANo Bueso, "Los derechos de los extranjeros en España: una perspectiva constitucional ", cit., págs. 24 y 25 . En alusión directa al Fundamento Jurídico $8^{\circ}$ de la STC 11/1981, de 8 de abril, al Fundamento Jurídico $3^{\circ}$ de la STC 13/1984, de 3 de febrero, y al Fundamento Jurídico $5^{\circ}$ de la STC 196/1987, de 11 de diciembre. 
La implantación del visado como único documento que permite entrar y trabajar legalmente en España.

Restringir la admisión de inmigrantes a las capacidades reales del mercado de trabajo.

Reforzar los controles de entrada para los extracomunitarios.

Agilizar los trámites de expulsión de los extranjeros denominados simpapeles.

Penalizar a los empresarios que contraten inmigrantes carentes de documentación.

De entre las novedades que apunta la reforma tratada a continuación cabe destacar la incorporación de visados de tres meses para que durante ese tiempo los inmigrantes busquen empleo en España.

Algunas tachas que ya han recaido sobre el texto que propone esta tercera reforma de la Ley de Extranjería, inciden en su marcado carácter policial dado que la reforma está muy centrada en agilizar los trámites y expedientes de expulsión de los inmigrantes ilegales o simpapeles. También se le critica al acuerdo sobre inmigración pactado por el gobierno y el primer partido de la oposición, el extremo que otorga demasiadas competencias a las compañías de transporte a la hora de verificar si los inmigrantes cumplen los requisitos de entrada legal en España. $Y$, lo que sin duda es más relevante, deja sin tratar las limitaciones de derechos de los extranjeros que contiene la normativa vigente.

\section{LATERCERA REGULACIÓN SOBRE EXTRANJERÍA ENTRES AÑOS (LA CUARTA DESDE 1985): \\ ANÁLISIS PRELIMINAR DE LA RECIENTE LEY ORGÁNICA 14/2003, DE 20 DE NOVIEMBRE, (BOE 21-XI-03)}

La que podríamos calificar como última o novísima Ley de Extranjería viene propiciada por la Ley Orgánica 14/2003, de 20 de noviembre, que entre otros extremos supone otra reforma de la Ley Orgánica 4/2000, de 11 de enero, sobre derechos y libertades de los extranjeros en España y su integración social, modificada a su vez por la Ley Orgánica $8 / 2000$, de 22 de diciembre. En lo atinente a la materia de extranjería podemos calificar como exitoso, en el sentido etimológico del término, el itinerario parlamentario surcado por la Ley Orgánica 14/2003. En el trámite parlamentario el texto que comentamos y destinado a entrar en vigor el 31 de diciembre de 2003 (al mes de su completa publicación en el Boletín Oficial 
del Estado, según su Disposición final cuarta), superó con amplio consenso su periplo tanto en el Senado como en el Congreso de los Diputados ${ }^{31}$. En realidad y tal como más arriba se ha anunciado estamos ante la cuarta alteración de la normativa sobre la materia de extranjería que se ha producido en nuestro país desde la Ley de 1985.

A pocos se escapa que está flamante modificación legislativa es la respuesta normativa española a la impronta que marca la Unión Europea desde la reunión de los jefes de Estado y de gobierno de los países miembros, celebrada en Tampere los días 16 y 17 de 1999 -ya aludida-, sobre la creación de un espacio de libertad, seguridad y justicia, así como el acervo de Schengen sobre régimen de entrada, condiciones de expedición de visados, regulación de la estancia de los extranjeros en suelo patrio, así como responsabilidad y sanciones a transportistas. Tampoco debemos olvidar que la reciente reforma pretende dar respuesta a las apreciaciones derivadas de la sentencia del Tribunal Supremo de 23 de marzo de 2003, relativas a la necesaria regulación interna de determinados preceptos del Reglamento de ejecución de la Ley Orgánica 4/2000, aprobado por Real Decreto 864/2001, de 20 de julio.

La teologia que orienta los postulados de Tampere 1999 busca plasmación en una normativa interna como la española guiada por los principios de ordenación de los flujos migratorios, con arreglo al desarrollo de una inmigración respetuosa con los cauces legales y reforzando los mecanismos para incidir en la lucha contra la inmigración ilegal o/y organizada. Entre los objetivos que sobre el papel se propone la Ley Orgánica 14/2003 merece ser destacado el favorecimiento de la inmigración legal y la integración de los extranjeros que, de esta manera, accedan y residan en territorio español. También el reforzamiento y mejora de los medios e instrumentos sancionadores previstos en las Leyes Orgánicas 4/2000 y 8/2000.

La "reforma de la reforma de la reforma», es decir, el último retoque de la Ley de Extranjería constata lo que en el texto que precede hemos calificado como evidencia, es decir, la necesidad de dar respuesta a las exigencias que plantea abordar la inmigración como hecho estructural que ha convertido a España en un país de destino de los flujos migratorios. Aún así, se hace patente que la última modificación legal se propone endurecer la entrada de inmigrantes irregulares al territorio español, y para ello con-

31 La reciente reforma sobre extranjería pasa por ser la modificación normativa sobre inmigración más consensuada de la democracia: 254 votos a favor correspondientes a PP, PSOE y CC, 14 votos en contra de IU, Grupo Vasco y Mixto, y 12 abstenciones pertenecientes a los diputados catalanes de CiU. 
cita la diligencia de profesionales y empresas de transporte mediante la reactivación de las oportunas sanciones para los transportistas que trasladen inmigrantes clandestinos. El mismo texto, convertido ya en norma vigente a primero de enero de 2004, instaura un trámite fronterizo como es el visado para buscar trabajo y que igualmente se expide ante la presencia de malos tratos. Cuenta la nueva norma con una adición sensible a la limitación de las llamadas "reagrupaciones familiares en cadena". En lo concerniente a la reagrupación familiar, so pretexto de evitar fraudes, la Ley Orgánica 14/2003 incorpora como presupuesto para el ejercicio de dicho derecho por parte de un residente que lo fuese en virtud de una previa reagrupación, el que éste sea titular de una autorización de residencia independiente, así como determinados requisitos concretos para el ejercicio de la reagrupación familiar en el caso de ascendientes previamente reagrupados. Llama la atención, al respecto, que igualmente se detallen los supuestos en los que los cónyuges e hijos reagrupados pueden acceder a una autorización de residencia independiente, para lo que en todo caso se exige que cuenten con una previa autorización para trabajar.

Además, la recién reformada Ley de Extranjería suprime la exención de visado para los extranjeros que eventualmente podrían lograr un permiso de residencia en nuestro pais por razones humanitarias, por colaborar abiertamente con la Administración de Justicia, por proceder de un país en situación bélica o por padecer enfermedad susceptible de tratamiento en nuestro suelo. En materia de visado se lee una función adicional a la que cabria esperar de dicho documento. Es decir, tras la Ley Orgánica 14/2003, el visado servirá como acreditación documental de una previa autorización administrativa para residir $y$, en su caso, trabajar en España. Ahora, pues, el visado no sólo sirve para entrar en nuestro territorio, sino que también habilita a su tenedor o titular para permanecer en suelo nacional en la situación para cuyo fin haya sido concedido $y$, en su caso, para trabajar.

En el haber de la reforma comentada cabe reseñar el planteamiento del Observatorio contra el Racismo, que incidirá en los pronósticos de integración como clave y revulsivo de las percepciones sobre extranjería y alteridad. Entre la síntomatología positiva que presenta la flamante reforma, tal como más arriba indicamos, cabe citar la simplificación de los trámites burocráticos necesarios para emitir un único visado de empleo $y$ residencia. Es claro que en este último extremo una más adecuada y mejor gestión, así como simplificación de los trámites administrativos evitará conductas torticeras y, sobre todo, impedirá un uso fraudulento de los procedimientos administrativos de gestión en esta materia, ( $v$. gr. requisito de la personación del interesado). 
No obstante, en su debe anotaremos que la Ley Orgánica 14/2003 representa una nueva vuelta de tuerca normativa para poner cerco a las personas que accedieron a territorio español sin documentos oportunamente validados, hasta el punto de contemplar la expulsión de los extranjeros que se vean acusados de un delito antes de que se dicte sentencia con las precisas garantías. La subrayada reforma sobre derechos y libertades de los extranjeros en España mantiene cercenados para los extranjeros el disfrute de los principales derechos sociales que la Constitución española de 1978 reconoce a todos los ciudadanos, tales como el derecho de reunión, el derecho de asociación, el derecho de manifestación y el derecho de huelga, además de cercenar la confidencialidad de los datos. personales al franquear a la policía cuantos datos obren en los censos. sobre los extranjeros; en particular en el padrón municipal. Reseñemos, no obstante, que estos extremos resultaron particularmente controvertidos en sede parlamentaria (Congreso de los Diputados) a la hora de debatir el texto -en su día- de lege ferenda. Así los grupos parlamentarios opuestos a la reforma y, dicho sea de paso, sin opciones reales de gobierno nacional (IU, PNV, CiU y Grupo Mixto), restaron enteros a la mencionada reforma precisamente aduciendo en sede parlamentaria el recorte de dichos derechos fundamentales a los inmigrantes. Por tanto, las coincidencias en torno al nuevo texto legal residen básicamente en la necesidad de una gestión eficaz tanto en la ordenación y el control de los flujos migratorios que llegan a España, y en la mejora de los dispositivos de acogida, atención y, por supuesto, promoción de la integración de los inmigrantes: en nuestra realidad social. Sin embargo, aspectos como los indicados relativos a la creación de un nuevo visado de tres meses para búsqueda de trabajo, y el correlativo endurecimiento de las penas y sanciones por contratación de inmigrantes en situación irregular, hacen un flaco favor a la pretendida teleología integradora de la reforma ${ }^{32}$.

Con todo y tras este rápido repaso a la Ley Orgánica 14/2003, la cuestión que no deja de merodear con cierta pulsión en el pensamiento de los analistas no es otra que la siguiente: ¿para cuándo la próxima reforma de nuestra normativa sobre extranjería?

32 Conviene reseñar que la Ley Orgánica 14/2003, de 20 de noviembre, de reforma. de la Ley Orgánica 4/2000, de 11 de enero, sobre derechos y libertades de los extranjeros en España y su integración social, modificada por la Ley Orgánica 8/2000, de 22 de diciembre, retoca igualmente la Ley $7 / 1985$, de 2 de abril, reguladora de las bases del régimen local, afecta también a la Ley 30/1992, de 26 de noviembre, de régimen jurídico de las Administraciones públicas $y$ del procedimiento administrativo común, y del mismo modo modifica la Ley 3/1991, de 10 de enero, de competencia desleal. 


\section{GARANTIAS DE LOS DERECHOS}

Más arriba hemos incluido entre el primer grupo de derechos aquellos denominados universales o incondicionales que corresponden sin distinción tanto a los nacionales como a los extranjeros, con independencia de su situación administrativa y catalogación legal. Como cabe imaginar, sobre este grupo de derechos recae el mayor vigor tuitivo de las garantias constitucionales dispuestas al efecto por la Carta Magna. Pero no vamos a hacer aquí una reseña lineal y descriptiva de las tipologías de garantías constitucionales que se ciernen sobre los derechos y libertades del Capítulo II del Título I de nuestra Constitución. La sola mención a las garantías institucionales, a las garantías normativas y a las garantías jurisdiccionales deben situarnos en la lógica argumental ya clásica predicada desde 1789 por el artículo 16 de la Declaración de Derechos del Hombre y del Ciudadano, precepto angular según el cual en una sociedad en la que la garantía de los derechos no está asegurada, no se puede decir que sea una sociedad regida por un verdadero orden constitucional. De manera que las garantías son la taumaturgia de la plena vigencia y eficacia de los derechos fundamentales.

Las garantías son, pues, instrumentos jurídicos y técnicos de aseguramiento de los derechos y libertades $y$, por ende, del valor normativo de la Constitución. Se trata de unos instrumentos que han de permitir la preservación o el restablecimiento de los derechos cuando éstos se vean empañados ante actuaciones de los poderes públicos o ante vulneraciones provenientes de otros particulares. De ahí que la Constitución española de 1978 haya otorgado particular relevancia al sistema de protección de los derechos y libertades fundamentales en torno a la consabida clasificación ya adelantada, (garantías institucionales, garantías normativas, garantías jurisdiccionales).

Centrados primeramente en las garantías normativas encontramos que el ordenamiento constitucional español presenta algunos instrumentos de tutela bajo la forma de derechos concretos que garantizan aspectos de otro derecho del cual dimanan. Así las garantías denominadas normativas se caracterizan, entre otros rasgos, por integrarse en el devenir del propio derecho que se garantiza, de manera que con su regulación y con su ejercicio queda determinada su propia protección ${ }^{33}$. Las garantías norma-

${ }^{33} \mathrm{El}$ art. 9.1 CE es significativo al respecto. Si bien el art. 53.1 CE reitera la vinculación de los poderes públicos y de los particulares a los derechos contenidos en el Capítulo II del Titulo I, (arts. 14 a 38). Por su parte el art. 53.3 CE establece que el reconocimiento, respeto y protección de los principios reconocidos en el Capitulo III del Título I, informará la legislación positiva, la práctica judicial y la actuación de los poderes públicos. 
tivas giran en torno a la vinculación de los poderes públicos y los particulares, a la reserva de ley, a las garantías sobre el contenido de los derechos, a las garantías que adoptan la forma de derechos, a la exención de obligaciones, a las exigencias y prohibiciones a los poderes públicos, y también a la rigidez constitucional ${ }^{34}$.

En materia de extranjería creo necesario incidir en los llamados derechos-garantía. De entre ellos es probablemente el más significativo de todos el derecho a la tutela judicial efectiva reconocido en el artículo 24 de la Constitución $n^{35}$. La tutela judicial efectiva consagrada constitucionalmente se configura como un derecho-garantía de todos los demás derechos, en el bien entendido de que la obtención de la tutela efectiva de los administradores de la justicia es uno de los instrumentos jurídicos más relevantes para la protección concreta y real de los derechos, (derecho de acceso al proceso, acceso a la jurisdicción, derecho a acceder a los recursos, formalismo-antiformalismo, indefensión, derecho al juez ordinario predeterminado por la ley, evitación de dilaciones indebidas, presunción de inocencia, derecho a usar los medios de prueba necesarios para la defensa, derecho a la ejecución de lo resuelto o a la eficacia de las resoluciones judiciales) ${ }^{36}$.

Tan relevantes como las garantías normativas son también en materia de extranjería las garantías jurisdiccionales. Éstas se definen como las garantías que pueden ser instadas por los interesados para prevenir 0 reparar la vulneración de un derecho fundamental del que son titulares. A través de esta garantía se encomienda a los jueces y tribunales, titulares en exclusiva de la función jurisdiccional, la tutela efectiva de los derechos e intereses legitimos de los extranjeros, (art. 24.1 CE).

La garantía jurisdiccional presupone la comprensión de la Constitución como norma jurídica de eficacia inmediata y directa, o bien alternativamente el reconocimiento de estos derechos a través de la legislación ordinaria. Una protección jurisdiccional específica de los derechos y libertades está prevista en el artículo 53.2 de la Constitución para el principio de igualdad aplicable también a los extranjeros, así como para los dere-

${ }^{34}$ Yolanda Gómez SÁnchez, Derechos y Libertades, ed. Sanz y Torres S.L., Madrid, 2003, pág. 343 y ss..

${ }^{35}$ Vid. Gregorio Cámara VILLAR, Votos Particulares y Derechos Fundamentales en la práctica del Tribunal Constitucional Español (1981-1991), Ministerio de Justicia, Secretaría General Técnica, Madrid, 1993, págs. 227 a 229. Y, Javier JiMÉNEZ CAMPO, Derechos Fundamentales: concepto y garantías, Trotta, Madrid, 1999, pág. 132 y ss.

${ }^{36}$ Sigo la sistemática empleada por el profesor CÁmARA VILLAR en su libro Votos. Particulares y Derechos Fundamentales en la práctica del Tribunal Constitucional Español (1981-1991), ob. cit., págs. 227 y ss.. 
chos reconocidos en la Sección Primera del Capítulo II del Título I de la Constitución. En relación con estos derechos fundamentales la propia Constitución declara que cualquier ciudadano podrá recabar la tutela de las libertades y derechos reconocidos en dicho grupo sistemático (arts. 14 a 29 +30 ) ante los tribunales ordinarios por un procedimiento basado en los principios de preferencia y sumariedad $y$, en su caso, a través del recurso de amparo ante el Tribunal Constitucional. Estamos, pues, ante dos procedimientos diferentes y sucesivos que cursan ante dos jurisdicciones distintas, es decir, el recurso preferente y sumario seguido ante los tribunales ordinarios y el recurso de amparo ante el Tribunal Constitucional. Esta dualidad procedimental da lugar a que podamos hablar de recurso de amparo ordinario, con la complejidad que implica la pluralidad de órdenes jurisdiccionales y las especificidades de algunos derechos, y el recurso de amparo constitucional.

Tenemos que concluir que el procedimiento de garantía de los derechos fundamentales basado en los principios de preferencia y sumariedad previsto en el artículo 53.2 de la Constitución, no es otro que el reseñado para tres modalidades tuitivas en la preconstitucional Ley 62/1978, de 26 de diciembre, de protección jurisdiccional de los derechos fundamentales de la persona. Ésta y no otra sería la vía judicial previa a la interposición del recurso de amparo que nos propone el 53.2.

La Ley 62/1978, de 26 de diciembre, ha sido amplificada en la práctica forense como instrumento específico relativo a las garantías jurisdiccionales de los derechos y libertades. Según el articulado de la Ley 62/1978 nos encontramos con tres manifestaciones procesales de dicha garantía jurisdiccional. A saber: la garantía jurisdiccional penal, la garantía jurisdiccional contencioso-administrativa, y la garantía jurisdiccional civil. Ahora bien, desde 1998, el procedimiento preferente y sumario en el orden contencioso-administrativo se halla regulado, sin embargo, en la Ley 29/1998, reguladora de la jurisdicción contencioso-administrativa (arts. 114 a 122 de dicha Ley), con lo cual queda derogada la anterior normativa que comprendía los artículos 6 a 10 de la Ley 62/1998.

Es patente que la Ley 62/1978 presenta una considerable laguna en el orden laboral o social. La laguna ha sido cubierta por medio de diferentes prescripciones contenidas al respecto en la vigente Ley de Procedimiento Laboral (R.D. Legislativo 521/1990, de 27 de abril, arts. 174 a 181). En cuyo ámbito quedarian inmersos los derechos laborales o sociales atinentes a los extranjeros empleados en España.

Si las eventuales vulneraciones de derechos y libertades provienen de la propia Administración de Justicia (v. gr. lesiones del derecho a la tutela judicial efectiva y del principio de igualdad procesal), tenemos que acu- 
dir al inespecifico sistema de recursos intrínsecos a la actividad jurisdiccional. Los recursos ordinarios han de permitir. un cauce de reparación frente a resoluciones judiciales definitivas y no firmes. Mientras que si se trata de vulneraciones originadas por resoluciones judiciales inatacables o firmes, no existe procedimiento alguno que atienda a los postulados de preferencia y sumariedad expresados por el artículo 53.2 de la Constitución. Lo que supone que ante tales supuestos sólo resta la protección ofrecida por elTribunal Constitucional, no obstante prevista con carácter subsidiario a través de su propio recurso de amparo (constitucional).

Ahora bien, con relación a los extranjeros que se encuentren en España se detectan situaciones concretas que por su singularidad están precisadas de normativa ad hoc. Así la protección de determinados derechos que comprenden a los extranjeros de modo incondicional: por ejemplo la libertad personal prevista en el artículo 17 de la Constitución con carácter universal, y que se encuentra tutelada específicamente a través del procedimiento de habeas corpus (art. 17.4 CE), desarrollado por la Ley Orgánica 6/1984, conforme a la cual habría que preguntarse cual es la situación del inmigrante extranjero carente de documentación que es detenido en la frontera y alojado, seguramente contra su voluntad, en establecimientos de detención creados al efecto ${ }^{37}$.

Asimismo los derechos de reunión desarrollados en la Ley Orgánica 9/1983, en cuanto cercena las reuniones no autorizadas, naturalmente, de extranjeros indocumentados. Tuvimos ocasión de examinar más arriba que el derecho de reunión y manifestación, ex art. 21, tenía sensibles mermas para según qué clase de extranjeros (vid. en sentido restrictivo de este catálogo, el tercer grupo de derechos que antecede).

Por su parte, la vigente Ley de extranjería establece diversas garantías juridicas en el ejercicio de los derechos reconocidos. De entre ellas son garantías incondicionadas o universales para cualquiera que sea el extranjero las siguientes:

- Derecho a la tutela judicial efectiva.

- Derecho al intérprete.

- Derecho a las garantías en todo tipo de procedimiento administrativo, comprensivas del acceso a los recursos y a las condiciones generales de ejecutividad de los actos administrativos.

37 Cfr. José Angel MARín GÁmEz, "Las demandas de asilo en los puestos fronterizos", en la revista del CiSS, Noticias de la Unión Europea, núm. 143, diciembre 1996, año XII, págs. 25 a 30. 
- Reconocimiento de la legitimidad de las organizaciones constituidas válidamente para la defensa de las personas inmigrantes, comprensiva de la legitimación para intervenir en los procesos administrativos en que así sean designadas.

- Derecho a la asistencia jurídica gratuita en los términos establecidos legalmente, extensible a cualquiera sea la persona extranjera sin distinción, tanto en procedimientos judiciales como administrativos sobre denegación de entrada, devolución o expulsión del territorio español, y en los relativos a las peticiones de asilo ${ }^{38}$.

Entre las garantías generales cabe reseñar el derecho de plantear queja ante el Defensor del Pueblo, y que comprende a todas las personas sean o no extranjeros, con independencia de su situación legal o administrativa. Frente a la vulneración de derechos y libertades constitucionales o de los derechos contenidos en la normativa de desarrollo, esta queja es admisible ante el Defensor del Pueblo como alto comisionado de las Cortes Generales de España, así como ante el Defensor del Pueblo Andaluz.

En definitiva, ello supone que a los extranjeros les ha de ser aplicable el régimen de garantías previsto constitucionalmente para los derechos, sin que sea lícito establecer diferencias de trato ni en el grado de protección que llevan aparejados dichos derechos. En materia de garantías, si cabe, la apuesta debe ser más radical ya que el régimen de garantías constituye un elemento determinante de los derechos fundamentales que ha de permanecer inalterable sea cual sea la nacionalidad de su titular. En palabras del profesor Cano Bueso ${ }^{39}$, no es jurídicamente admisible recortar el nivel, estándar o eficacia que tiene un derecho cuando su titular es un extranjero. Lo que no significa, en modo alguno, que los extranjeros no puedan sufrir limitaciones en el ejercicio de los derechos cuya titularidad les corresponde. Limitaciones que han de obedecer en todo caso al principio de legalidad en cualquiera de sus manifestaciones, y sujetarse a reglas de ponderación y proporcionalidad.

38 J.A. MARín GÁmEZ, "Las demandas de asilo en los puestos fronterizos ", cit., pág. 27 y ss.

39 Juan CANo Bueso, "Los derechos de los extranjeros en España: una perspectiva constitucional , cit., pág. 29. 


\section{A MODO DE CONCLUSIÓN}

Las cifras que hemos manejado en el presente estudio son bastante elocuentes y si se me permite hasta indicativas de que en el futuro los extranjeros en situación irregular seguirán entrando a buen ritmo en nuestro país, y que lo harán por todos los medios imaginables; eso todavía sin ponderar suficientemente que la emigración subsahariana no ha hecho más que empezar, aunque ésta presenta un elevado potencial de crecimiento puesto que para las personas procedentes de esas latitudes el hecho de emigrar se han convertido en una necesidad que forma parte del imaginario colectivo. Por tanto, concluyamos en primer término que indudablemente España será durante un tiempo dilatado un pais receptor de inmigrantes. En general, el reto que representa la inmigración para el mundo desarrollado pasa necesariamente por dar respuesta al menos a tres cuestiones cruciales:

1. ¿ ¿Cómo controlar los flujos migratorios?

2. ¿Qué políticas de integración llevamos a cabo?

3. ¿Cómo ayudamos al desarrollo de los paises pobres o en vías de desarrollo?

1. ${ }^{\text {a }}$ La primera de estas cuestiones puede encontrar respuesta en la: política común europea de inmigración, ahora apoyada en un sistema de vigilancia común. Es decir, se puede afirmar que los países comunitarios han de compartir una misma politica fronteriza: $y$ de visados. En términos cuantitativos, uno de los principales problemas que plantea la inmigración no es la llegada de los denominados ilegales, sino el control de los que vienen bajo la: apariencia de legalidad para quedarse irregularmente. Ahora bien, los líderes de los quince actuales países miembros de la. Unión Europea reiteraron a mediados de octubre de 2003, en Bruselas, la necesidad de poner en marcha un sistema de gestión eficaz de las fronteras externas de la Unión, teniendo para ello en cuenta la ampliación del ámbito territorial de la Unión tras la incorporación en 2004 de los diez paises candidatos a formar: parte militante del concierto europeo. Para ello los Quince han diseñado la creación de una Agencia de Gestión de las Fronteras que aparte de reunir a expertos en la materia, relanza la idea de establecer un sistema europeo de cuotas de inmigrantes por países receptores de los mismos ${ }^{40}$. Así los líderes europeos parecen

${ }^{40}$ Cumbre de Bruselas, de 16 de octubre de 2003. Se establece que el control de los flujos migratorios es una cuestión de máxima prioridad para la Unión Europea. La 
decantarse por la idea lanzada por los ministros de Interior en septiembre de 2003, en Roma, de que se establezca un sistema de cuotas, atendiendo al país de origen del inmigrante, para dosificar la entrada de extranjeros en el territorio de la Unión Europea. Si bien, debe quedar a salvo cierto margen de actuación de cada país comunitario a la hora de acoger responsablemente el número de inmigrantes que admiten las necesidades laborales de su mercado interior. Por tanto, la cuestión planteada exige crear canales suficientemente amplios para la inmigración legal, y en paralelo intensificar la presión sobre el subempleo y el trabajo informal. La flexibilidad en la gestión administrativa del fenómeno migratorio puede ser un instrumento útil a tener en cuenta para no disociar la realidad de las previsiones ${ }^{41}$. Seguramente así se pueda alterar un dato constatable como es que la inmigración ocupa uno de los últimos lugares entre las prioridades presupuestarias de la Unión Europea.

2. A la segunda cuestión da igualmente respuesta una política europea que proponga reglas comunes mínimas de integración en todo el territorio de la Unión. La cumbre de los Quince celebrada en Bruselas en octubre de 2003 incide en la necesidad de desplegar una política común de inmigración que combine medidas para evitar la inmigración ilegal con la integración social de los inmigrantes cuya situación se encuentra regularizada ${ }^{42}$. En este sentido es necesario que la emigración deje de ser utilizada como moneda de cambio en las relaciones bilaterales entre Estados ricos y pobres. En lo inmediato y más cercano, atendiendo a la inmigración que nos llega en condiciones muy precarias desde el

citada cumbre de Bruselas exige a los ministros de Justicia e Interior que antes de fin de 2003, alcancen un acuerdo sobre la directiva que regulará los procedimientos en materia de asilo, y en relación con la Agencia de Gestión de las Fronteras, se encarga a la Comisión que presente una propuesta para que los jefes de Estado puedan cerrar un acuerdo al acabar el ejercicio anual. Los cometidos de la Agencia de Gestión de las Fronteras serán la coordinación de las actividades nacionales al efecto, formar agentes y financiar proyectos comunes de vigilancia fronteriza.

41 En la actualidad la gestión administrativa y los retrasos en la obtención de los permisos necesarios para la deseada regularización del extranjero, tardan una media de ocho meses hasta verificarse en el mejor de los casos. La complejidad de los trámites y su duración redundan negativamente en la calidad de vida del inmigrante y en la paciencia del empleador.

$42 \mathrm{Cfr}$. con las cumbres de Tampere y Salónica. 
sur, bueno sería liberalizar las exportaciones agrícolas a la Unión Europea que provienen, por ejemplo, de Marruecos ${ }^{43}$.

$3^{a}$. Se sale al paso de la tercera cuestión planteada mediante la cooperación internacional a través de inversiones que permitan estabilizar a las poblaciones en sus países de origen. La ayuda pública y privada al desarrollo es clave para atajar debidamente, aunque a medio y largo plazo, el hecho que supone la inmigración desde los países pobres al mundo desarrollado. Ayuda que en todo caso ha de quedar vinculada a la democratización y construcción del Estado de Derecho en las sociedades menos avanzadas. Mientras los desequilibrios económicos sean tan agudos dentro de los países de origen y, del mismo modo, mientras no se corrijan los escandalosos desequilibrios sociales y económicos que existen entre países ricos y países pobres, la presión migratoria seguirá existiendo e incrementándose. De ahí que se revele esencial la necesidad de usar los instrumentos adecuados en el ámbito de las relaciones internacionales para robustecer la cooperación e implicar decididamente a países terceros. Sin olvidar que el fomento de una auténtica liberalización política en los paises de emigración puede producir efectos favorables ahora insospechados. En este sentido Europa y Occidente en general tienen mucho que aportar. Sólo una negociación multilateral en la que abiertamente se impliquen los paises receptores de inmigrantes y los países de procedencia puede arrojar luz a estos problemas, encauzando así la ola migratoria mediante la acción combinada de medidas de seguridad, ayuda al desarrollo, apertura de mercados, e inversión generadora de riqueza y empleo.

No es de recibo esperar a que las pandemias que asolan África se conviertan en nuestros aliados. No es de recibo esperar a que se cumplan los vaticinios que auguran un descenso generalizado de la natalidad para observar pasivamente qué camino toma un tema tan sensible como éste. Seamos realistas, estimaciones como esas no dejarían de tener un impacto marginal sobre la cuestión relativa a los flujos migratorios. Es necesaria una verdadera y rotunda ley o leyes de integración. Porque la rigidez de los procedimientos administrativos arbitrados para conseguir la regularización, genera una bolsa creciente de indocumentados que es necesario reducir dado que éste es el auténtico peligro social contra la convivencia y

${ }^{43}$ En el país magrebi vecino casi el $40 \%$ de la población activa está empleado en actividades agropecuarias. 
la integración social. Las verdaderas tareas pendientes que afrontamos con el actual reto que supone la inmigración son, principalmente, ordenar la llegada de inmigrantes y trabajar de modo resuelto en favor de la integración. Esta tarea será a buen seguro empresa que el legislador deje en manos del texto reglamentario que habrá de desarrollar la nueva Ley de Extranjería, cuya entrada en vigor se espera que ocurra en enero de 2004.

Finalmente, creo que cabe reformular conclusivamente una consideración que ha sobrevolado el texto que antecede, puesto que ya hemos indicado que la inmigración genera no pocos problemas, pero que igualmente resuelve otros tantos. La creciente presión migratoria que estamos llamados a experimentar, unida a la también creciente necesidad que nuestra sociedad tiene de trabajadores para desempeñar determinados empleos, nos urge a realizar una notoria operación de mentalización sobre la comunidad en que vivimos para que acepte - de buen grado - convertirse en una colectividad multiétnica y multicultural, y así se puedan desarrollar las mejores condiciones para la convivencia social. Conviene ir yugulando el tratamiento de las políticas migratorias desde las estrecheces de la denominada "razón de Estado" y la seguridad interior, para reubicar la percepción de los extranjeros ya establecidos y que con distinta suerte han ocupado los trabajos más ingratos, aunque necesarios para la construcción común, en el terreno del constitucionalismo social. Si la Constitución española de 1978 no contempla los derechos de los extranjeros con cicatería, sino con vocación de plenitud jurídica y social, postergando razones de seguridad interna o derivadas de políticas globalizadoras, ahora es el momento de seguir mirando a Europa. En una coyuntura histórica determinada por los avances y la ampliación de la Unión Europea, confiemos en que la futura Constitución europea sea sensible a esta realidad y contemple un estatuto jurídico para los extranjeros que sea asimilable al de los ciudadanos de la Unión. 